\title{
Patient-specific Induced Pluripotent Stem Cells as a Platform for Disease Modeling, Drug Discovery and Precision Personalized Medicine
}

\section{Wilson Young', Sunita L. D'Souza2,4, Ihor R. Lemischka ${ }^{2,3,4}$ and Christoph Schaniel ${ }^{2,4 *}$}

${ }^{1}$ Department of Medicine, Division of Cardiology, Mount Sinai School of Medicine, New York, NY, USA

${ }^{2}$ Department of Developmental and Regenerative Biology, Mount Sinai School of Medicine, New York, NY, USA

${ }^{3}$ Department of Pharmacology and Systems Therapeutics, Mount Sinai School of Medicine, New York, NY, USA

${ }^{4}$ Black Family Stem Cell Institute, Mount Sinai School of Medicine, New York, NY, USA

\begin{abstract}
The breakthrough development of induced pluripotent stem cell (iPSC) technology is not only revolutionizing basic stem cell science but is also spurring efforts to reprogram one somatic cell type directly into another. Induced pluripotent stem cells provide scientists with a self-renewing and, thus, unlimited, source of pluripotent cells for targeted differentiation, in principle, into the entire range of cell types found in the body. Therefore, iPSC technology and the increasingly refined abilities to differentiate iPSCs into disease-relevant mature cells has far reaching implications for understanding disease etiology and promoting drug discovery and other advances in regenerative medicine. In this review, we summarize the latest progress in the application of patient-specific iPSCs for disease modeling, drug screening and cell replacement therapy, and discuss their impact on precision personalized medicine.
\end{abstract}

Keywords: Induced pluripotent stem cell; Reprogramming; Patientspecific; Disease modeling; Drug discovery; Therapeutics; Precision personalized medicine

\section{Introduction}

The establishment of human embryonic stem cells (hESCs) in 1998 together with their unlimited self-renewal potential and ability to differentiate into any cell type of the body has raised hopes for drug discovery and regenerative medicine [1]. However, the challenges related to bioethics, safety and the limited availability of diseasespecific hESC lines have complicated the realization of these hopes. This changed dramatically in 2006 when Kazutoshi Takahashi and Shinya Yamanaka made the seminal discovery that mouse skin fibroblasts can be reprogrammed into an induced pluripotent stem cell (iPSC) state that shares the indefinite self-renewal and pluripotent differentiation capacities of ESCs using a simple cocktail of pluripotency transcription factors [2]. One year later, these same investigators as well as groups headed by James Thomson and George Daley succeeded in converting human fibroblasts into hiPSCs [3-5]. Reprogramming to pluripotency has now been demonstrated starting with a variety of somatic cell types [6-13]. Taken together these advances enable the generation of patientand disease-specific hiPSCs as avenues for exploring disease etiology, developing novel drugs, toxicology screening and, in the future, cell replacement therapies.

\section{Reprogramming Cell Fates}

Historically the ground-work for reprogramming was established by Hans Spemann in 1938 [14]. Using a hair to constrain the nucleus to one side of a newly fertilized salamander egg he was able to show that the side with the nucleus could divide but not the side without it. Once the hair was loosened, after four cell divisions creating a 16cell embryo, the nucleus slipped back into the separated cytoplasm, and cell division began on this side as well. After a few divisions, Spemann then tightened the hair loop again, and broke apart the two embryos. A twin set of salamanders developed, one slightly younger than the other. This experiment demonstrated that the nucleus retains totipotency even after having undergone four divisions. It was not until 1952 that Spemann's "fantastical experiment", the transfer of a nucleus from an older embryo into an egg, was successfully executed by Briggs and King [15]. The two authors described the development of normal embryos after the transplantation of nuclei from advanced blastula cells into enucleated eggs of the frog Rana pipiens. This was truly the first successful nuclear transfer experiment. Ten years later Sir John Gurdon using the Xenopus system transferred terminally differentiated intestinal epithelial cell nuclei into unfertilized eggs and demonstrated that $1.5 \%$ of the transferred nuclei successfully developed into tadpoles [16]. This experiment demonstrated that nuclei from terminally differentiated cells remain totipotent. Sir Ian Wilmut reported the successful creation of a cloned mammal in 1997 when he and his colleagues cloned Dolly the sheep by fusing a somatic donor cell nucleus with an enucleated oocyte [17]. In 1998, Wakayama and colleagues reported similar results in mice by injecting cumulus cell nuclei into enucleated metaphase II oocytes [18].

Nuclear Reprogramming, the process that reverts the epigenetic state of a nucleus particular to one specialized cell type to that of a different cell type, can be achieved by heterokaryon formation. Helen Blau and colleagues established the stable heterokaryon system by fusing human amniotic, non-muscle cells with terminally differentiated multinuclear mouse myotubes in 1983 [19]. These heterokaryons did not divide and retained two complete sets of chromosomes. Nevertheless, the mouse muscle cell nuclei were sufficient to activate human muscle-specific genes. Acquiring pluripotency in a somatic cell was first described by M. Azim Surani and colleagues by fusing mouse thymic lymphocytes with embryonic germ cells [20]. The hybrid cells showed dramatic

*Corresponding author: Christoph Schaniel, Department of Developmental and Regenerative Biology, Mount Sinai School of Medicine, New York, NY, USA, E-mail: christoph.schaniel@mssm.edu

Received July 13, 2012; Accepted September 17, 2012; Published September 19, 2012

Citation: Young W, D'Souza SL, Lemischka IR, Schaniel C (2012) Patientspecific Induced Pluripotent Stem Cells as a Platform for Disease Modeling, Drug Discovery and Precision Personalized Medicine. J Stem Cell Res Ther S10:010. doi:10.4172/2157-7633.S10-010

Copyright: (C) 2012 Young W, et al. This is an open-access article distributed under the terms of the Creative Commons Attribution License, which permits unrestricted use, distribution, and reproduction in any medium, provided the original author and source are credited. 
changes in the epigenetic state of the somatic cell nucleus that now resembled the germ cell state. In addition, the hybrid cells were able to differentiate into a variety of tissues in chimeric embryos thus proving functional pluripotency. In 2001, Takashi Tada's group demonstrated that ESCs contain the factors required to reprogram somatic cell nuclei by fusing thymocytes with ESCs [21].

Reprogramming by ectopic expression of "master regulator" genes was first described in 1987 by Walter Gehring's group in Drosophila [22]. Flies, with ectopically expressed homeotic Antennapedia gene, developed secondary legs instead of antennae. In the same year, Harold Weintraub and colleagues demonstrated that ectopic expression of a single myogenic basic helix-loop-helix transcription factor MyoD in non-muscle cells induced myogenesis, and stably converted C3H10T1/2 fibroblasts into myoblasts [23].

\section{Reprogramming of Somatic Cells to Induced Pluripotent Stem Cells}

In 2006, Yamanaka and Takahashi hypothesized that somatic cells could revert into a pluripotent, self-renewing ESC state when exposed to a defined set of factors expressed in ESCs and cultured in conditions that favor pluripotent cell growth. Using a retroviral system, they forced expression of a selected set of 24 candidate genes in mouse embryonic fibroblasts (MEFs) and were successful in establishing clones that possessed ESC-like morphologies, proliferation rates, expressed ESC markers and had demethylated the promoter of the Nanog gene [2]. These cells were termed as induced pluripotent stem cells (iPSCs). Removing one factor at a time Takahashi and Yamanaka further demonstrated that a minimum set of only four factors namely, Klf4, cMyc, Oct4 and Sox2 were necessary for reprogramming MEFs as well as tail-tip fibroblasts from adult mice into iPSCs. Later studies showed that the presence of $\mathrm{cMyc}$ is not an absolute reprogramming requirement but its absence significantly reduces the efficiency of the process [24].

The successful reprogramming of human somatic cells to hiPSCs was reported within one year [3-5]. Takahashi and Yamanaka, as well as Daley's group used KLF4, cMYC, OCT4 and SOX2, the same factors as in the mouse system, to convert human fibroblasts into iPSCs $[3,4]$. The Thomson group achieved the same results using LIN28, NANOG, OCT4 and SOX2 [5].

Since then the field of cellular reprogramming has progressed at an unprecedented pace. Specific advances include the use of various cell types, including, keratinocytes, terminally differentiated neurons, lymphocytes, hair follicle dermal papilla cells and even tumor cells for reprogramming [6-13], and the replacement of individual factors by other regulators [25-29], small molecules [27,30-40] or a modified culture condition [41]. There are also studies that provide insights into the molecular mechanism of the reprogramming process [30,42-48]. To facilitate the transition of this technology into the clinic, the vector system has gradually evolved from integrating viral systems, which may cause insertional mutagenesis and thus pose a risk for translational application of the technology, to non-integrating systems as evidenced by the use of adenovirus [49], plasmids [50-52], excisable viruses [5355], episomal or minicircle vectors [56,57], piggyBac transposons [58-60], proteins [61], Sendai virus [62], synthetic mRNAs [63], and microRNA mimics [64].

Furthermore, iPSC lines have been derived from species other than mice or humans, including rhesus monkey [65], marmoset [66] rat $[34,67]$, pig [68-70], dog [71,72], sheep [73], horse [74] and cow
[75]. These lines will allow us to genetically engineer these animals, facilitating the generation of large(r) animal disease models. An additional potential use of iPSC technology is the preservation of endangered species [76], possibly extending to the resurrection of extinct ones. Of course a number of obstacles, including suitable embryo culture and identification of an appropriate surrogate mother species need to be resolved before this can become a reality.

\section{Direct Reprogramming of One Somatic Cell Lineage to Another}

As mentioned above, successful reprogramming of mammalian somatic cells to myoblasts by ectopic expression MyoD was already reported in 1987 [23]. Thomas Graf and his group succeeded in identifying the minimal set of transcription factors sufficient to transdifferentiate one hematopoietic cell lineage into another. Gatal was sufficient to convert myelomonocytic cells into erythrocytes [77], while Cebpa or Cebpb transformed B-lymphocytes into macrophages [78]. Transduction of both Cebpa and Sfpil (PU.1) was required to switch T cells into macrophages [79].

It took the success of iPSC reprogramming to rekindle a broad interest in direct reprogramming of one somatic cell lineage into another. Because attempts to identify a single "master" regulator have failed for most cell lineages, scientists started to look for combinations of factors. The first such successful reprogramming was surprisingly achieved in vivo by Doug Melton and his group, by converting differentiated pancreatic exocrine cells in adult mice into cells that closely resembled endocrine $\beta$-cells with a combination of three transcription factors [80]. This seminal study was soon followed by a flurry of in vitro examples of reprogramming fibroblasts into various distinct somatic cell lineages, including, neurons [81-85], neural progenitors [86], neurosphere-like cells [87], neural stem cells [88-90], hepatocyte-like cells [91,92], and cardiomyocytes [93-97]. In addition to the conversion of pancreatic exocrine to endocrine cells [80], in vivo somatic cell reprogramming has so far been achieved only for cardiomyocytes $[94,97,98]$. Direct reprogramming is straightforward and rapid. One remaining obstacle is low efficiency precluding the generation of sufficient target cell numbers for downstream applications (see below).

Sheng Deng's group demonstrated an alternative approach for directed lineage conversion from fibroblasts to another somatic cell type by transient expression of the four Yamanaka factors followed by culture conditions favoring non-pluripotent, specialized cell types such as cardiomyocytes and neural progenitors $[99,100]$. In this case, it is possible that the factors serve to erase the epigenetic fibroblast state and the culture conditions select for random or stochastic epigenetic resetting events. This is also the likely mechanism for the reported generation of hematopoietic progenitors after expression of Oct4 [101].

\section{Disease Modeling}

Conventional human disease research is performed using platforms such as epidemiology, genetics, genomic and epigenomic profiling, animal models as well as various, sometimes heterologous, in vitro cell culture models. However, these approaches are often accompanied by several complications. First, human tissue or cell samples are often difficult to obtain, sometimes requiring invasive surgery as in the case of the heart or brain, or available only after the patient's death. Second, generally the isolated cells cannot be maintained or expanded with current culture conditions, except if rendered immortal. However, immortalization by genetic manipulation alters normal cell physiology and thus renders any data and analyses obtained from the modified 
cells, highly questionable. Third, animal models are only suitable if the physiology of the experimental species is comparable to humans. And fourth, heterologous cell culture models, although convenient, easily accessible, and widely utilized will nevertheless lack the typical biological, physical and physiological features of the diseased human cell. The technology of patient- or disease-specific iPSC derivation coupled with directed differentiation to appropriate target cells circumvents these obstacles and provides several additional advantages. First, hiPSCs can be generated from patients with genetic diseases and, therefore, the derived target cells thus possess the same genetic background as the patient. This is important because an individual's genetic makeup can profoundly influence disease progression, its severity, as well as the elicited drug response. One example of an adverse effect of the latter is drug-induced cardiac arrhythmia. Second, the ability of correct genetic disease-associated lesions (see below) in patient-derived iPSCs increases their potential for eventual cellbased therapies. In a proof-of-principle study Hanna and colleagues demonstrated that a mouse sickle cell anemia model could be treated by transplantation of hematopoietic progenitor cells derived from "autologous" iPSCs with a repaired sickle hemoglobin allele [102].

\section{Disease Selection, Patient Recruitment and Cell Sampling}

The first step in hiPSC-based disease modeling is choosing a disease or syndrome. Careful selection of a disorder for patient-specific iPSCs disease modeling is a critical step and may predetermine the likelihood of success. In general, genetic disorders are easier to model than those caused by predominant epigenetic or environmental factors. Monogenetic disorders with a clear disease phenotype are easier to model than complex genetic disorders. The same holds true, for congenic or familial diseases compared to sporadic diseases. Nevertheless, there are clear examples of successful hiPSC-based disease modeling of complex disorders, including sporadic Alzheimer's disease [103] and Schizophrenia [104,105] (see also Table 1). After choosing a disease the next step is applying for internal review board approval to recruit patients and conduct the study. With approval, suitable patients are recruited, informed about the process and study, their consent obtained, and finally skin, blood or other tissue/cell samples are collected. The least invasive way to obtain cells is by drawing blood from the patient. Another convenient and easy way is to perform a skin biopsy under local anesthesia using a $2-4 \mathrm{~mm}$ biopsy punch without a suture. Once the tissue or cell samples are collected, they need to be expanded. For example, one method involves the separation of the buffy coat fraction from blood, followed by expansion of T-cells in the presence of IL-2 and activating antibodies CD3 and CD28 for 4-6 days [12]. One fraction of these cells are used for quality control assays, another fraction banked for future DNA finger printing studies and one fraction used for iPSC generation. Fibroblasts, on the other hand, can routinely be grown from skin biopsies, expanded using standard tissue culture conditions, and then subjected to similar quality control and banking procedures as described for blood cells.

\section{Patient-specific iPSC Derivation, Expansion and Banking}

Reprogramming can be achieved using the various methods described above. For simplicity and reproducibility, we prefer the non-integrating Sendai virus or Stemgent's latest synthetic mRNA/ microRNA transfection methods (Brad Hamilton, Stemgent, presentation at ISSCR $10^{\text {th }}$ Annual Meeting, June 13-16, 2012). Both methods are similarly robust for reprogramming patient- or disease- specific fibroblasts. Reprogramming of blood-derived cells is currently only feasible using Sendai virus but this technical issue will likely be resolved in the near future. Reprogramming with mRNA/microRNA has the advantage that once hiPSCs are established they can be used immediately for downstream studies. In contrast, hiPSCs derived using Sendai virus need to be selected for absence of the virus, which can take up to 8-10 passages or 6-10 weeks. If patient-specific iPSCs or their derivatives are considered for cell replacement then the derivation process needs to be performed under Good Manufacturing Practice (GMP) conditions.

Irrespective of the derivation method, properly reprogrammed clones need to be identified and expanded. This requires familiarity with pluripotent stem cell (PSC) morphology and proper passaging techniques. An inherent problem of hiPSC derivation and expansion is that individual hiPSC lines are heterogeneous with respect to their growth properties and differentiation abilities. The reasons for such heterogeneity are currently unclear. Selection of accurately reprogrammed, "true" hiPSC lines may be facilitated by "live"-staining for pluripotency-associated cell surface markers such as TRA-1-60 or TRA-1-81 [106]. Established hiPSC lines need to be DNA fingerprinted to ensure that they originate from the donor cell source and are not contaminated by other cell lines. In addition, the newly generated hiPSC lines need to fulfill a set of criteria to confirm complete reprogramming and pluripotency [107-109]. These include PSC morphology, unlimited self-renewal, expression of molecular pluripotency-associated markers, pluripotency gene promoter demethylation, and functional in vitro and/or in vivo ability to differentiate into derivatives of to all three germ layers. Currently there is a need for a consensus minimal set of criteria that can be used in multiple studies. This will enable rigorous crosslaboratory comparisons. Furthermore, such a minimal set of criteria is necessary for studies focused on complex, multi-factorial diseases that will require the recruitment of many patients. As an example, currently many groups perform in vivo teratoma assays in immunodeficient mice to assess pluripotency. This is costly and labor intensive and clearly, cannot be routinely performed for numerous hiPSC lines. This as well as other criteria are currently the subject of lively discussions $[107,108]$. There is also an ongoing debate as to how many passages are required to completely erase the epigenetic programs of the starting cell populations $[110,111]$. In addition, selection of high-quality patientspecific iPSC lines would be dramatically improved by identification of molecular markers that would predict hiPSC differentiation potential.

Established hiPSC lines that meet to the above criteria need to be expanded for banking. Before cryopreservation, expanded lines should be tested for a normal karyotype. However, standard karyotyping methods will not detect small chromosomal aberrations or point mutations, and more sophisticated approaches such as comparative genomic hybridization or whole-genome sequencing may be required. Currently, these are costly but are rapidly becoming affordable. Overall, the extent of necessary characterization of iPSC lines may also be guided by specific downstream applications.

\section{Disease Correction}

Genetic correction of the disease-associated mutation(s) in patientspecific iPSC lines serves several purposes. First, it will generate isogenic control cells that differ only in the particular mutation(s) from the original patient-specific iPSC line. These disease-corrected hiPSCs are the perfect control for any comparative analyses of disease phenotype. Second, these disease-corrected hiPSCs and their differentiated target cells could eventually be applied in cell replacement therapies. 
Citation: Young W, D’Souza SL, Lemischka IR, Schaniel C (2012) Patient-specific Induced Pluripotent Stem Cells as a Platform for Disease Modeling Drug Discovery and Precision Personalized Medicine. J Stem Cell Res Ther S10:010. doi:10.4172/2157-7633.S10-010

Page 4 of 14

\begin{tabular}{|c|c|c|c|}
\hline Disorder & Affected Gene(s) & Phenotype assessment & Reference(s) \\
\hline a1-antitrypsin deficiency & SERPINA1 & Aggregation of misfolded alpha1-antitrypsin in the endoplasmic reticulum & [182] \\
\hline Adrenoleukodystrophy, X-linked & Unknown & iPSC-oligodendrocytes exhibit very long chain fatty acid level & [183] \\
\hline Alzheimer's disease, familial & $\begin{array}{l}\text { PSEN1, PSEN2 } \\
\text { APP }\end{array}$ & $\begin{array}{l}\text { iPSC-neurons have increased amyloid } \beta 42 \text { secretion, phosphorylated-Tau and active } \\
\text { glycogen synthase kinase- } 3 \beta \text { as well as accumulation of large Rab5 } 5^{+} \text {early endosomes }\end{array}$ & {$[103,154]$} \\
\hline Alzheimer's disease, sporadic & Unknown & $\begin{array}{l}\text { Increased levels of amyloid- } \beta \text {, phosphorylated-Tau and active glycogen synthase } \\
\text { kinase- } 3 \beta \text { as well as accumulation of large Rab5 } 5^{+} \text {early endosomes }\end{array}$ & [103] \\
\hline Amyotrophic lateral sclerosis, familial & $T A R D B P$ or $V A P B$ & $\begin{array}{l}\text { TARDBP iPSC neurons have elevated levels of soluble and detergent-resistant TDP- } \\
43 \text { protein, decreased survival in longitudinal studies, and increased vulnerability to } \\
\text { antagonism of the PI3K pathway; VAPB fibroblasts, iPSCs and hiPSC neurons have } \\
\text { reduced levels of VAPB }\end{array}$ & {$[184,185]$} \\
\hline $\begin{array}{l}\text { Catecholaminergic polymorphic ventricular } \\
\text { tachycardia type } 1\end{array}$ & CASQ2 or RYR2 & $\begin{array}{l}\text { iPSC cardiomyocytes are arrhythmogenic, have delayed afterdepolarizations, after- } \\
\text { contractions, and exhibit higher amplitudes and longer durations of spontaneous } \mathrm{Ca}^{2+}- \\
\text { release }\end{array}$ & {$[150,186-188]$} \\
\hline Chronic granulomatous disease, $\mathrm{X}$-linked & CYBB or NCF1 & iPSC neutrophils or iPSC-macrophages lack ROS production & {$[189,190]$} \\
\hline $\begin{array}{l}\text { Chronic infantile neurological cutaneous } \\
\text { and articular syndrome }\end{array}$ & NLRP3 & iPSC marcophages show abnormal IL1 $\beta$ secretion & [191] \\
\hline Chronic myelogenous leukemia & $B C R-A B L$ & iPSC mature but not immature hematopoietic cells are sensitive to imatinib & [192] \\
\hline Dilated cardiomyopathy & LMNA or Tnnt2 & $\begin{array}{l}\text { iPSC-fibroblasts have nuclear membrane abnormalities, increased senescence and } \\
\text { susceptibility to apoptosis; iPSC-cardiomyocytes show altered regulation of } \mathrm{Ca}^{2+} \text {, } \\
\text { decreased contractility, abnormal distribution of sarcomeric } \alpha \text {-ACTININ, and cellular } \\
\text { stress upon stimulation with a } \beta \text {-adrenergic agonist }\end{array}$ & {$[193,194]$} \\
\hline Down syndrome & Trisomy 21 & $\begin{array}{l}\text { iPSC teratoma microvessel density is significantly reduced (reference 195); iPSC- } \\
\text { neurons processed the transmembrane APP protein, resulting in secretion of the } \\
\text { pathogenic peptide fragment amyloid- } \beta 42 \text {, a feature of Alzheimer's disease (reference } \\
\text { 196) }\end{array}$ & {$[195,196]$} \\
\hline Dyskeratosis congenita & $\begin{array}{l}\text { DKC1, TERC or } \\
\text { TCAB1 }\end{array}$ & iPSC show progressive telomere shortening and loss of self-renewal & {$[197,198]$} \\
\hline Familial Dysautonomia & IKBKAP & $\begin{array}{l}\text { Decreased expression of genes involved in neurogenesis and neuronal differentiation; } \\
\text { defects in neural crest migration }\end{array}$ & [151] \\
\hline Familial Hypercholesterolemia & $L D L R$ & $\begin{array}{l}\text { hiPSC-derived hepatocytes have an impaired ability to incorporate LDL, increased } \\
\text { secretion of lipidated ApoB- } 100\end{array}$ & {$[182,199]$} \\
\hline Fragile $\mathrm{X}$ syndrome & FMR1 & iPSC show aberrant neuronal differentiation with loss of expression of FMRP & [200] \\
\hline Gaucher's disease type III & $G B A$ & $\begin{array}{l}\text { iPSC-neurons have compromised lysosomal protein degradation, accumulation of } \\
\text { a-SYNUCLEIN and neurotoxicity through aggregation-dependent mechanisms }\end{array}$ & {$[201]$} \\
\hline Glycogen storage disease type $1 \mathrm{~A}$ & G6PC & $\begin{array}{l}\text { iPSC-hepatocytes hyperaccumulate glycogen and lipid, and have excessive production } \\
\text { of lactic acid }\end{array}$ & [182] \\
\hline Huntington's disease & HTT & $\begin{array}{l}\text { iPSC-neural stem/progenitor cells show enhanced caspase activity upon growth } \\
\text { factor deprivation; iPSC asctrocytes show cytoplasmic vacuolation; iPSC but not iPSC } \\
\text { neurons have significantly increased lysosomal activity }\end{array}$ & {$[115,202-205]$} \\
\hline $\begin{array}{l}\text { Hurler syndrome (Mucopolysaccharidosis } \\
\text { type I) }\end{array}$ & IDUA & $\begin{array}{l}\text { iPSC have an imbalance between production and clearance of unprocessed GAG and } \\
\text { show lysosomal storage defects }\end{array}$ & [206] \\
\hline Hutchinson-Gilford progeria & $\angle M N A$ & $\begin{array}{l}\text { iPSC mesenchymal stem cells, vascular smooth muscle cells and fibroblasts display } \\
\text { progerin accumulation, increased DNA damage, and nuclear abnormalities; iPSC- } \\
\text { vascular smooth muscle cells also show premature senescence, blebbing and } \\
\text { increased apoptosis }\end{array}$ & {$[193,207,208]$} \\
\hline Juvenile Diabetes * & $L D L R$ & iPSC hepatocytes show features of hypercholesteremia & [199] \\
\hline LEOPARD syndrome & PTPN11 & $\begin{array}{l}\text { iPSC cardiomyocytes reveal features of cardiac hypertrophy (increased size, increased } \\
\text { sarcomere organization and increased nuclear localization of NFATC4) }\end{array}$ & {$[140]$} \\
\hline Long QT 3 and Brugada overlap syndrome & SCN5A $A^{1798 i n s D /+}$ & $\begin{array}{l}\text { iPSC cardiomyocytes show reduced upstroke velocity and longer action potential } \\
\text { duration }\end{array}$ & [209] \\
\hline Long QT syndromes & $\begin{array}{l}\text { KCNQ1 (LQT1); } \\
\text { KCNH2 (LQT2), } \\
\text { SCN5A (LQT3), } \\
\text { CACNA1C (LQT8/ } \\
\text { Timothy syndrome) }\end{array}$ & $\begin{array}{l}\text { iPSC cardiomyocytes have a prolonged action potential duration reminiscent of } \\
\text { delayed repolarization, early afterdepolarization (LQT3), and irregular contraction, } \\
\text { excess } \mathrm{Ca}^{2+} \text { influx, irregular electrical activity and abnormal calcium transients (LQT8/ } \\
\text { Timothy syndrome) }\end{array}$ & \\
\hline Machado-Joseph disease & ATXN3 & $\begin{array}{l}\text { iPSC neurons show formation of SDS-insoluble aggregates after } \mathrm{Ca}^{2+} \text {-dependent } \\
\text { proteolysis of ATXN3 }\end{array}$ & {$[216]$} \\
\hline Marfan syndrome & FBN1 & $\begin{array}{l}\text { iPSC show inhibition of osteogenic differentiation, enhanced TGF } \beta \text {-signaling, and } \\
\text { chondrogenic differentiation without TGF } \beta 1 \text { media supplementation }\end{array}$ & {$[217]$} \\
\hline
\end{tabular}


Citation: Young W, D'Souza SL, Lemischka IR, Schaniel C (2012) Patient-specific Induced Pluripotent Stem Cells as a Platform for Disease Modeling, Drug Discovery and Precision Personalized Medicine. J Stem Cell Res Ther S10:010. doi:10.4172/2157-7633.S10-010

Page 5 of 14

\begin{tabular}{|c|c|c|c|}
\hline Mucopolysaccharidosis type IIIB & NAGLU & $\begin{array}{l}\text { iPSCs and differentiated neurons derived from patients show defects in storage } \\
\text { vesicles and Golgi apparatus }\end{array}$ & {$[218]$} \\
\hline Parkinson's disease, familial & $\begin{array}{l}\text { LRRK2, SNCA or } \\
\text { PINK1 }\end{array}$ & $\begin{array}{l}\text { iPSC dopaminergic neurons show impaired mitochondrial function; iPSC dopaminergic } \\
\text { neurons have increased expression of key oxidative stress response genes and } \\
\text { a-synuclein protein, and increased sensitivity to oxidative-stress; accumulation of } \\
\text { autophagic vacuoles }\end{array}$ & {$[156,219-223]$} \\
\hline Polycythaemia vera & $J A K 2$ & iPSC hematopoietic cells have enhanced erythropoiesis & [224] \\
\hline Pompe disease & GAA & $\begin{array}{l}\text { iPSC cardiomyocytes show high levels of glycogen and multiple ultrastructural } \\
\text { aberrances }\end{array}$ & [225] \\
\hline Prader-Willi syndrome & $\begin{array}{l}\text { Translocation of } \\
\text { the paternally } \\
\text { expressed } \\
\text { chromosome } \\
15 q 11-q 13 \text { region } \\
\text { to chromosome } 4\end{array}$ & $\begin{array}{l}\text { iPSCs express reduced levels of the disease-associated small nucleolar RNA HBII-85/ } \\
\text { SNORD116 }\end{array}$ & {$[226]$} \\
\hline Retinitis pigmentosa & $\begin{array}{l}R P 1, R P 9, P R P h 2 \\
\text { or } R H O\end{array}$ & $\begin{array}{l}\text { iPSC rod cells numbers are decreased, express markers for oxidation or endoplasmic } \\
\text { reticulum stress, and show different responses to vitamin E }\end{array}$ & {$[227]$} \\
\hline Rett Syndrome & MECP2 & $\begin{array}{l}\text { iPSC neurons have decreased synapse number, reduced number of spines, a reduction } \\
\text { in soma size, altered calcium signaling, and elevated LINE1 retrotransposon mobility }\end{array}$ & {$[153,228-231]$} \\
\hline Schizophrenia & Unknown & $\begin{array}{l}\text { iPSC neurons showed diminished neuronal connectivity in conjunction with decreased } \\
\text { neurite number, PSD95-protein levels and glutamate receptor expression; iPSC } \\
\text { neurons have an increase in extra-mitochondrial oxygen consumption as well as } \\
\text { elevated levels of reactive oxygen species }\end{array}$ & {$[104,105]$} \\
\hline Sickle cell disease & $H B B$ & Marginally increased HBB mRNA levels & {$[117]$} \\
\hline Spinal muscular atrophy & SMN1 & $\begin{array}{l}\text { iPSC motor neurons have a reduced size and decrease in numbers over time; show an } \\
\text { abnormality in neurite outgrowth }\end{array}$ & {$[152,232]$} \\
\hline Timothy syndrome & CACAN1C & $\begin{array}{l}\text { iPSC cardiomyocytes have irregular contraction, excess } \mathrm{Ca}^{2+} \text { influx, prolonged action } \\
\text { potentials, irregular electrical activity and abnormal calcium transients } \\
\text { iPSC cortical neurons have defects in } \mathrm{Ca}^{2+} \text {-signaling and activity-dependent gene } \\
\text { expression, as well as abnormalities in cortical neuron differentiation }\end{array}$ & {$[212,233]$} \\
\hline Werner syndrome, atypical & LMNA & $\begin{array}{l}\text { iPSC fibroblasts show nuclear membrane abnormalities, increased senescence and } \\
\text { susceptibility to apoptosis }\end{array}$ & [193] \\
\hline Wilson's disease & ATP7B & iPSC hepatocytes mislocalize mutated ATP7B and have defective copper transport & [234] \\
\hline
\end{tabular}

*see also Familial Hypercholesteremia

Table 1: Patient-specific iPSCs with described disease phenotypes.

There exist several molecular approaches for gene targeting to correct and also introduce genetic mutations into the genome of cells. The classical approach is using homologous recombination technology. This method is successfully used in mouse PSCs but is very inefficient in hPSCs as demonstrated by the small number of published reports (see references in [112]). Nevertheless, three recent reports have demonstrated the feasibility of using classical homologous recombination to repair an underlying genetic mutation in patient-specific iPSCs. In one case for gyrate atrophy [113], in another case for $\beta$-thalassemia major or Cooley's anemia [114], and in the third case for Huntington's disease [115]. A second approach to genetically correct a disease-associated mutation in hiPSCs is by using the highly efficient system of helper-dependent adenovirus-mediated homologous recombination [116]. A third way of gene-editing can be accomplished using site-specific zinc finger nucleases (ZFNs) in combination with an exogenous donor vector that carries homologous sequences needed for homology-directed repair of the ZFN-mediated precise DNA double strand break. Incorporation of a drug resistance cassette into the donor vectors allows for selection of targeted cells and thus increases the success rate. Flanking of this cassette with either loxP or FRT sites allows for its removal by transient expression of Cre- or Flp-recombinase, respectively. This approach has been successfully employed in repairing disease-associated mutations in patient-specific iPSCs, namely for the mutated $\beta$-GLOBIN allele causing sickle cell disease $[117,118]$ or the dominant A53T mutation in $\alpha$-SYNUCLEIN that is associated with Parkinson's disease [119]. An alternative, similar to ZFN in approach and robustness, but apparently simpler technique is transcription activator-like effector nuclease (TALEN)-mediated gene targeting. TALENs are designed after natural TALEs, a class of DNA binding proteins expressed by plant pathogenic bacteria that can subvert the host's genome regulatory network [120]. TALENs that recognize precisely predetermined sequences in the genome can be easily designed and assembled. They have been successfully used to efficiently modify the genomes of many species and cell types, including hESCs and hiPSCs [121]. However, to date no report exists of TALENmediated gene correction in patient-specific hiPSC. This is clearly only a matter of time.

RNA interference (RNAi) technology can be an innovative approach to rescue disease-associated phenotype(s). Because of its potency and high mRNA target specificity, RNAi provides an ideal opportunity to inhibit alleles of genes showing inherited or acquired polymorphisms and alternative or cryptic splicing with single point mutations found in inherited diseases. The functional utility of RNAimediated selective suppression of mutant mRNAs in dominant human genetic disorders has been established (for examples see references in [122]). The feasibility of RNAi to revert a disease-phenotype in patientspecific iPSCs has been demonstrated in the neurological disorder Friedreich's ataxia where shRNA silencing of the mismatch repair enzyme MSH2 impeded the disease-associated GAA/TTC repeat expansion [123]. 


\section{Directed Differentiation}

Disease modeling, drug discovery and future cell replacement therapies rely heavily on efficient and homogeneous differentiation of hiPSCs to appropriate specialized cells. Many years of work have defined protocols for differentiation of hESCs and more recently hiPSCs to distinct cell types, including neurons, cardiomyocytes and hepatocytes, mimicking pathways of human development. Protocols for differentiation to more specialized cell subsets, such as nodal, atrial, ventricular or Purkinje fiber cardiomyocytes, have not yet been established but will be critical for modeling specific disorders and for drug discovery. In many cases the differentiation process has been developed for particular cell lines and often is not similarly robust in a broad range of hPSC lines without individual, line-specific modifications. In addition, the process is often inefficient and produces a heterogeneous cell population consisting of multiple cell types and/or a mixture of cells at different developmental stages, mostly consisting of fetal or immature phenotypes (to name a few examples: cardiomyocytes [124,125], dendritic cells [126], neural cells [127], and pancreatic $\beta$-cells [128]). Small molecules that mimic growth factors and directly activate developmental programs would reduce not only the cost of differentiation (recombinant growth factors are expensive) but also alleviate the batch-to-batch variability in protein activity. Unfortunately, small molecules do not yet exist for most growth and developmental conditions. Nevertheless, the number of reports describing differentiation protocols that incorporate or exclusively use small molecules is growing [129-133] and development of such protocols is part of ongoing research in numerous laboratories. Another complicating component that contributes to variability in disease modeling or drug discovery is the multistep nature of the differentiation process that can take several weeks or even months depending on the specific target cell population. Overall, the single most critical consideration for any large( $\mathrm{r}$ )-scale analysis or screening purpose is the ability to scale-up the expansion and differentiation process and retrieve pure specialized target cells. Demonstrating the feasibility of the former has primarily been concentrated on the reproducible and homogeneous proliferation of undifferentiated hPSCs using bioreactors [134-137], but there are only a few reports on scalable, controlled and regulated differentiation [134,138,139]. Pure differentiated cell populations can be achieved by enrichment using fluorescence-activated cell sorting or magnetic bead separation. However, for many specialized human cells appropriate surface antigens and corresponding antibodies have not yet been identified. In addition, certain target cells may require co-culture with support/niche cells for proper differentiation, maturation or survival.

\section{Disease Modeling: Identification and Analysis of Cellular Disease Phenotypes}

The concept of in vitro disease modeling with patient-specific iPSCs is very attractive and is based on their unique ability to self-renew indefinitely, their potential to give rise to all cell types in the body and their matching genetic identity with a particular patient. However, the key to any disease modeling is the availability of a measurable diseaserelevant phenotype, such as electrophysiological abnormalities in cardiomyocytes derived from cardiac disease patient-specific iPSCs. Measurable phenotypes are more likely to be found in monogenetic disorders with a clearly identified disease phenotype than in complex genetic disorders such as Autism, which are more complicated to model. Furthermore, to control for the inherent variability among hiPSC lines derived from the same patient several lines (generally, at least three) should be examined. A pressing and re-occurring issue in the field of hiPSC-based disease modeling is "What constitutes an appropriate control cell?" relative to which the obtained analytical data can be evaluated. Human iPSC lines derived from un-affected close relatives, i.e. parents, siblings or children, that share $50 \%$ identity of the genetic information with the patient, are considered suitable controls. However, at least for monogenic Mendelian disorders, patient-specific iPSCs in which the underlying disease-associated mutation has been corrected (see above) are undoubtedly the best controls because of their isogenic nature, aside, of course, from the mutation. Despite the concerns raised above, successful modeling of several monogenic, familial and even sporadic disorders with patient-specific iPSCs has been accomplished (Table 1). We were part of the team that established the first human cardiac disease model with LEOPARD syndrome (LS) patient-specific iPSC by modeling the hypertrophic cardiomyopathy phenotype found in LS patients with mutations in the PTPN11 gene [140].

Future research will undoubtedly move towards the comparison of hiPSC lines from many patients with the same disorder and/or mutation. Such comparative analyses will help address whether interpatient differences in clinical disease progression and severity can be modeled in vitro. If this were the case, and we are confident that this is possible, then comparative disease modeling opens the door to the search for the underlying genetic and/or epigenetic component(s) responsible for these differences. Along the same line, hiPSCs derived from select groups of people with acquired symptoms/disorders such as drug-induced arrhythmias or insulin-resistance, and an appropriately selected non-affected control population may enable the identification of the respective underlying mechanism(s). Clearly, there is great potential here for combining hiPSC disease modeling with genomewide association studies (GWAS) to uncover assemblies of loci that collectively contribute to complex multifactorial diseases [141-143]. Given the complexity of such diseases, issues such as the ability to generate numerous hiPSC lines from many patients, the development of robust differentiation protocols, minimizing line to line variability, obtaining suitable numbers of controls from unaffected individuals, etc. become extremely relevant. With large numbers of hiPSC lines from affected and unaffected populations coupled with the power of GWAS it may be possible to identify causative or predisposing genetic loci using powerful statistical approaches [144,145]. Understanding these genetically- and/or epigenetically-influenced disparities between individual groups may lead to better diagnostic predictors, possibly, earlier detection and hopefully the development of fine-tuned, personalized therapeutics.

\section{Drug Evaluation, Discovery and Development}

Currently, the development of pharmaceutical therapeutics is a very inefficient process. A large majority of identified candidate drugs fail to reach the market because of safety concerns (about one third of pharmaceuticals are withdrawn due to cardiotoxicity [146]) and efficacy issues. The weakness in the current drug development model is that drug responses measured in animal models cannot be used to predict efficacy in humans. Genetically modified rodents and immortalized human cell lines also fail to replicate human conditions. In contrast to these systems, iPSC technology can accurately replicate disease-specific cell types within the disease-relevant genetic context allowing for better high-throughput screening assays to select for a candidate drug's therapeutic response as well as toxicity. Moreover, the use of hiPSC in screening could decrease the number of animals sacrificed during drug testing [147]. 
An early example of a hiPSC-based drug screen is from Tanaka and colleagues [148]. They differentiated hiPSC to cardiomyocytes expressing cardiac markers including NKX2-5, GATA-4 and atrial naturetic peptide as well as cardiac specific forms of sodium, potassium and calcium channels. Using multi-electrode arrays (MEAs), Tanaka and colleagues measured changes in the electrophysiological properties of these hiPSC-derived cardiomyocytes in response to different ion channel inhibitors namely, quinidine, verapamil, and a potassium channel blocker [148]. Their study showed that hiPSCderived cardiomyocytes and native cardiomyocytes responded similarly to various pharmacologic agents. Another study showed the ability of hiPSC-derived cardiomyocytes to respond to amiodarone, isoproterenol, procainamide, mexilitine, and propranolol with respect to contractility and beating rate [149].

The pharmaceutical compound dantrolene was found to rescue the arrhythmogenic defect in a patient-specific iPSC model of catecholaminergic polymorphic ventricular tachycardia 1 (CVPT1) caused by the S406L mutation in the cardiac ryanodine receptor type 2 (RYR2) gene [150]. This receptor mutation alters the frequency and duration of elementary $\mathrm{Ca}^{2+}$ release from the sarcoplasmic reticulum upon catecholaminergic stress and, thus, causes elevated diastolic $\mathrm{Ca}^{2+}$ concentrations, a reduced sarcoplasmic reticulum $\mathrm{Ca}^{2+}$ content and an increased susceptibility to delayed after-depolarizations and arrhythmia when compared to control cardiomyocytes. The authors postulated correctly that dantrolene, which is believed to stabilize the interaction between the N-terminal and central domains of RYR2 could suppress the effect of the S406L mutation, which is positioned at the interface between these two regions. Treatment of S406L RYR2 CVPT1 hiPSCderived cardiomyocytes with dantrolene indeed restored normal $\mathrm{Ca}^{2+}$ sparks and fluxes.

Recently, the first high-throughput drug screening study was published employing hiPSC-derived cardiomyocytes [146]. Employing a new 96-well MEA, this was a novel method for quantifying druginduced proarrhythmic risk. A monolayer of hiPSC-derived cardiomyocytes tested with 25 known pharmacologic agents evoked predicted responses from the cardiomyocytes. Furthermore, two known arrhythmogenic compounds induced arrhythmic impedance traces that were inhibited by calcium channel blockers. QT prolonging agents were also used and all of them induced a dose- and time-dependent irregular beating pattern reminiscent of torsade de pointes type arrhythmias. Therefore, at least in principle, iPSC derived cell lineages can be used not only for screening of therapeutic drug candidates but also for screening for the effects of known drugs.

Most studies employing hiPSCs in drug screening have been in neuronal diseases. Patient-specific iPSC lines have been created for various neuronal diseases such as familial dysautonomia (FD) [151], spinal muscular atrophy (SMA) [152], Rett syndrome [153], Alzheimer's disease [154,155] and Parkinson's disease [156] to name a few. Although the specific culture conditions needed for differentiation of hiPSCs into neuronal lineages for drug discovery applications are generally available, they require further refinements. Lee and colleagues modeled FD, a genetic disease of dysfunction of the autonomic and sensory nervous systems due to the incomplete development of and survival of sensory, sympathetic and some parasympathetic neurons caused by mutations in IKBKAP encoding for IkB kinase complex associated protein, using iPSC technology. Lee and colleagues found that the homozygous $2507+6 \mathrm{C}>\mathrm{T}$ mutation in $I K B K A P$ results in the expression of particularly low levels of normal, correctly spliced IKBKAP mRNA, defects in neurogenesis and neural crest cell migration [151]. Treatment of differentiating FD-iPSCs but not derived neural crest precursors with kinetin, a plant hormone, significantly increased the number of developing neurons and the expression of key peripheral neuron markers but not the neural crest cell migration defect. This study demonstrated that hiPSC-based drug discovery has good predictive value for therapeutics.

In a study focused on SMA, Ebert and colleagues employed patientspecific iPSC-derived motor neurons and astrocytes, recapitulating physiological characteristics of SMA with decreased expression of survival motor neuron protein-1 (SMN) [152]. Treatment of the patient-specific iPSC derived neural cells with valproic acid and tobramycin increased SMN protein levels suggesting that drug screening was possible in this system.

In another study by Marchetto and colleagues, hiPSC derived from a patient with Rett Syndrome, exhibited reduced spine density and neurons having smaller cell bodies [153]. Neurons derived from these hiPSCs were employed in a drug screen that identified IFG1 and gentamycin as being able to rescue synaptic defects.

Alzheimer's disease, a neurodegenerative disorder characterized by deposition of amyloid $\beta$ peptide $(\mathrm{A} \beta)$ formed from the precursor protein by sequential cleavage with $\beta$ - and $\gamma$-secretase, has also been modeled using patient-specific iPSCs [154,155]. These hiPSCs were differentiated into neuronal cells expressing the forebrain marker, FOXG1 and neocortical markers, CUX1, SATB2, CTIP2, and TBR1 as well as amyloid precursor protein, $\beta$-secretase and $\gamma$-secretase components [155]. Differentiated cells were capable of secreting $\mathrm{A} \beta$ into the conditioned medium. $\mathrm{A} \beta$ production was inhibited by $\beta$-secretase and $\gamma$-secretase inhibitors, as well as sulindac sulfide, a non-steroidal anti-inflammatory drug [155]. Therefore, patientspecific iPSC modeling of Alzheimer's disease is feasible and testing of candidate drugs with this system is possible [154,155].

Cooper and colleagues derived hiPSC from patients with Parkinson's disease with a mutation in PINK1 (PTEN-induced putative kinase 1) and LRRK2 (leucine-rich repeat kinase 2) genes. These hiPSCs were differentiated to neural cells and analyzed for mitochondrial function, including production of reactive oxygen species, mitochondrial respiration, proton leakage, and mitochondrial movement [156]. Mitochondrial dysfunction in hiPSC-derived neural cells from familial Parkinson's disease patients and at-risk individuals could be rescued with coenzyme $\mathrm{Q}(10)$, rapamycin, and the LRRK2 kinase inhibitor GW5074 suggesting that pharmacological rescue of mitochondrial deficits in these cells may result in a viable treatment option.

\section{Drawbacks and Potential Limitations}

Diseases are divided into three types, monogenetic diseases caused by a single mutation; multigenic diseases, caused by mutations in multiple genes and diseases caused by environmental factors. In addition, there are multiple diseases with more complex causalities involving interactions of genetic and environmental components. While patient-specific iPSC can model monogenetic diseases with a defined phenotype, multifactorial diseases require multiple tissue types and, thus, will be more challenging. Additionally, some diseases occur in late adulthood and would presumably require lengthy culture conditions for hiPSC modeling and even then the modeling may not represent true pathological conditions [157]. Also, incomplete target cell enrichment following differentiation is a problem that must be overcome [158] (see also above). Clonal variation of hiPSCs is 
also a problem because it requires generation and testing of at least several clones from each patient and comparison of phenotypes and differentiation potential of each clone. Moreover, the lesion ultimately responsible for a disease phenotype may manifest at a particular stage of differentiation. Therefore, effective drug screens will need to measure effects during the entire differentiation process. Currently, this is not feasible. Finally, adult manifested lesions may not be amendable to modeling using current iPSC technology due to the current inability to generate truly mature cell types from iPSCs (see above).

\section{Regenerative Medicine}

In principle, patient-specific iPSC are preferable to hESCs due to several reasons. First iPSC generation is not fraught with the ethical dilemma surrounding ESC generation $[159,160]$. Second, transplantation of allogenic ESC-derivatives requires immunosuppressive therapy and constant surveillance to prevent cell/ tissue rejection [161]. In theory, patient-specific iPSC-derived cellular transplantation should avoid the immune response since these cells are autologous. However, three issues still need to be addressed. First, although iPSC and ESC share most, if not all, functional properties, there have been reports of at least partially persistent epigenetic memory [111,162-166]. This might skew iPSC differentiation potential towards certain lineages. Second, there have been several reports that a variety of genetic lesions accrue during the reprogramming process [167-173]. The generality of these observations and whether they are a function of the specific reprogramming technologies are two open questions. A consensus will also have to be reached as to what is the acceptable level of potential genetic changes, in general, as well as for specific hiPSC applications. Finally, there have been reports from the murine system, that iPSCs may be immunogenic, even in syngeneic contexts [174]. When these issues are resolved, strategies for replacing cells that have died off in diseases such as Parkinson's, or cells that do not produce proper proteins or factors such as in Hemophilia might be ideal targets for hiPSC-based approaches. In addition, the prospect of correcting a gene mutation in patient-specific iPSCs and then transplanting the corrected differentiated somatic cells back into the disease-affected individual is tremendous.

Although iPSC-based therapies in humans are not yet feasible, several proof-of-concept studies in animals show promise. One of the first studies on iPSC therapy was accomplished by Wernig and colleagues using a rat model of Parkinson's disease [175]. Mouse fibroblasts were reprogrammed into iPSCs and then differentiated into neuronal precursors. These cells were then sorted for neuronal markers and injected into adult rats suffering from drug induced Parkinson's disease. The transplanted cells were shown to engraft into the adult rat brain and form axonal connections with native neurons. Furthermore, some functional dopaminergic neuronal recovery was observed in rats injected with iPSC-derived dopaminergic cell. In another study, $\mathrm{Xu}$ and colleagues injected the livers of irradiated hemophilia A mice with iPSC-derived endothelial cells that produced wild-type factor VIII (mutated in Hemophilia A patients) [176]. A bleeding assay determined that all transplanted mice survived due to the presence of functional Factor VIII. In another case, functional recovery of spinal cord injury was demonstrated by Tsuji and colleagues using normal iPSC-derived neurospheres that were transplanted into the brain of a spinal cord injury mouse model [177]. The mice exhibited functional re-myelination and axonal re-growth as well as differentiation of neurospheres into all three neuronal cell types including neurons, astrocytes and oligodendrocytes. As mentioned previously, correction of a disease-causing mutation has been demonstrated by Hanna and colleagues, who employed a humanized sickle cell anemia mouse model where iPSC bearing the sickle mutation were corrected by gene specific targeting [102]. Mice transplanted with hematopoietic progenitors derived from the corrected iPSCs exhibited restored hemoglobin function. Certainly the promise of regenerative therapies employing iPSCs or their derivatives are evident from these early studies. However, further studies must be done to address the safety of iPSC-based cell therapeutics before it can be transitioned into the clinic [178].

\section{Precision Personalized Medicine}

Precision personalized medicine describing the diagnostic, prognostic and therapeutic strategies precisely tailored to an individual patient's requirements is the future of effective patient treatment. This concept was predicted in the late 1800's by Canadian physician Sir William Osler who noted in 1892 "If it were not for the great variability among individuals, medicine might as well be a science, not an art." [179]. Although medicine will very much remain an art, the medical community is beginning to understand the role of inter-individual variability on patient therapy.

A modern and evolving area is to integrate personal genetic and genomic information, clinical patient assessment, family history and medical advances in order to tailor clinical therapeutics according to an individual patient's needs. This holistic, integrative approach is known as pharmacogenetics, if in reference to germ-line encoded differences in metabolic enzymes responsible for drug deposition. If in reference to the broader application of genomic technologies to drug discovery, efficacy and toxicity it is called pharmacogenomics. Current research interests include identification of the genetic basis of diseases, studying how genes and the environment interact to cause or influence the progression or severity of human diseases, and identification and application of pharmacogenetic biomarkers to facilitate more effective drug therapies. We refer the interested reader to the following literature for more detailed insight into these topics [179-181].

In the era of GWAS, where scientist and clinicians compile data on polygenetic linkage to complex multifactorial disorders, patientspecific iPSCs can provide a new model to explore the mechanisms of how polygenic modifications identified by GWAS contribute to disease pathology [142]. In addition, patient-specific iPSC-based pharmacogenomics, i.e., genomic and epigenomic profiling of diseaserelevant cell types derived from patient-specific iPSCs can provide invaluable synergistic information to classical GWAS. When the gathered knowledge is coupled with drug databases and/or hiPSC-based drug discovery screens, and the patient's clinical health information it may help predict the most effective and safest pharmaceutical therapy for the individual patient.

In conclusion, the combination of established clinicalpathophysiological indexes, GWAS, patient-specific iPSC disease modeling, drug evaluation, discovery and development, as well as hiPSC-based pharmacogenomics has the potential to unravel the causative or predisposing genetic loci of diseases ultimately resulting in improved diagnostic predictors, earlier detection and finally the development of individual patient-tailored therapeutics. This is true precision personalized medicine.

\section{Acknowledgement}

This work was supported by grants from the Empire State Stem Cell Fund 
Citation: Young W, D’Souza SL, Lemischka IR, Schaniel C (2012) Patient-specific Induced Pluripotent Stem Cells as a Platform for Disease Modeling Drug Discovery and Precision Personalized Medicine. J Stem Cell Res Ther S10:010. doi:10.4172/2157-7633.S10-010

through New York State Department of Health (NYSTEM) C024176 to I.R.L. and S.L.D., and C024410 to C.S. and I.R.L.

\section{References}

1. Thomson JA, Itskovitz-Eldor J, Shapiro SS, Waknitz MA, Swiergiel JJ, et al. (1998) Embryonic stem cell lines derived from human blastocysts. Science 282: $1145-1147$

2. Takahashi K, Yamanaka S (2006) Induction of pluripotent stem cells from mouse embryonic and adult fibroblast cultures by defined factors. Cell 126: 663-676

3. Yu J, Vodyanik MA, Smuga-Otto K, Antosiewicz-Bourget J, Frane JL, et al. (2007) Induced pluripotent stem cell lines derived from human somatic cells. Science 318: 1917-1920.

4. Takahashi K, Tanabe K, Ohnuki M, Narita M, Ichisaka T, et al. (2007) Induction of pluripotent stem cells from adult human fibroblasts by defined factors. Cell 131: 861-872.

5. Park IH, Zhao R, West JA, Yabuuchi A, Huo H, et al. (2008) Reprogramming of human somatic cells to pluripotency with defined factors. Nature 451: 141-146.

6. Hanna J, Markoulaki S, Schorderet P, Carey BW, Beard C, et al. (2008) Direct reprogramming of terminally differentiated mature $B$ lymphocytes to pluripotency. Cell 133: 250-264.

7. Aasen T, Raya A, Barrero MJ, Garreta E, Consiglio A, et al. (2008) Efficient and rapid generation of induced pluripotent stem cells from human keratinocytes. Nat Biotechnol 26: 1276-1284.

8. Utikal J, Maherali N, Kulalert W, Hochedlinger K (2009) Sox2 is dispensable for the reprogramming of melanocytes and melanoma cells into induced pluripotent stem cells. J Cell Sci 122: 3502-3510.

9. Tsai SY, Clavel C, Kim S, Ang YS, Grisanti L, et al. (2010) Oct4 and klf4 reprogram dermal papilla cells into induced pluripotent stem cells. Stem Cells 28: 221-228.

10. Miyoshi N, Ishii H, Nagai K, Hoshino H, Mimori K, et al. (2010) Defined factors induce reprogramming of gastrointestinal cancer cells. Proc Natl Acad Sci USA 107: 40-45.

11. Carette JE, Pruszak J, Varadarajan M, Blomen VA, Gokhale S, et al. (2010) Generation of iPSCs from cultured human malignant cells. Blood 115: 40394042.

12. Seki T, Yuasa S, Oda M, Egashira T, Yae K, et al. (2010) Generation of induced pluripotent stem cells from human terminally differentiated circulating $\mathrm{T}$ cells. Cell Stem Cell 7: 11-14

13. Kim J, Lengner CJ, Kirak O, Hanna J, Cassady JP, et al. (2011) Reprogramming of postnatal neurons into induced pluripotent stem cells by defined factors. Stem Cells 29: 992-1000.

14. Spemann H (1938) Embryonic Development and Induction. Yale University Press New Haven.

15. Briggs R, King TJ (1952) Transplantation of Living Nuclei From Blastula Cells into Enucleated Frogs' Eggs. Proc Natl Acad Sci USA 38: 455-463.

16. Gurdon JB (1962) The developmental capacity of nuclei taken from intestina epithelium cells of feeding tadpoles. J Embryol Exp Morphol 10: 622-640.

17. Wilmut I, Schnieke AE, McWhir J, Kind AJ, Campbell KH (1997) Viable offspring derived from fetal and adult mammalian cells. Nature 385: 810-813.

18. Wakayama T, Rodriguez I, Perry AC, Yanagimachi R, Mombaerts $\mathrm{P}$, et al. (1999) Mice cloned from embryonic stem cells. Proc Natl Acad Sci USA 96: 14984-14989.

19. Blau HM, Chiu CP, Webster C (1983) Cytoplasmic activation of human nuclear genes in stable heterocaryons. Cell 32: 1171-1180.

20. Tada M, Tada T, Lefebvre L, Barton SC, Surani MA (1997) Embryonic germ cells induce epigenetic reprogramming of somatic nucleus in hybrid cells. EMBO J 16: 6510-6520.

21. Tada M, Takahama Y, Abe K, Nakatsuji N, Tada T (2001) Nuclear reprogramming of somatic cells by in vitro hybridization with ES cells. Curr Biol 11: $1553-1558$.

22. Schneuwly S, Klemenz R, Gehring WJ (1987) Redesigning the body plan of Drosophila by ectopic expression of the homoeotic gene Antennapedia. Nature 325: 816-818.
23. Davis $\mathrm{RL}$, Weintraub $\mathrm{H}$, Lassar $A B$ (1987) Expression of a single transfected cDNA converts fibroblasts to myoblasts. Cell 51: 987-1000.

24. Nakagawa M, Koyanagi M, Tanabe K, Takahashi K, Ichisaka T, et al. (2008) Generation of induced pluripotent stem cells without Myc from mouse and human fibroblasts. Nat Biotechnol 26: 101-106.

25. Feng B, Jiang J, Kraus $\mathrm{P}, \mathrm{Ng} \mathrm{JH}$, Heng JC, et al. (2009) Reprogramming of fibroblasts into induced pluripotent stem cells with orphan nuclear receptor Esrrb. Nat Cell Biol 11: 197-203.

26. Heng JC, Feng B, Han J, Jiang J, Kraus P, et al. (2010) The nuclear recepto $\mathrm{Nr} 5 \mathrm{a} 2$ can replace Oct4 in the reprogramming of murine somatic cells to pluripotent cells. Cell Stem Cell 6: 167-174.

27. Moon JH, Heo JS, Kim JS, Jun EK, Lee JH, et al. (2011) Reprogramming fibroblasts into induced pluripotent stem cells with Bmi1. Cell Res 21: 13051315.

28. Nakagawa M, Takizawa N, Narita M, Ichisaka T, Yamanaka S (2010) Promotion of direct reprogramming by transformation-deficient Myc. Proc Natl Acad Sc USA 107: 14152-14157.

29. Zhao $Y$, Yin X, Qin H, Zhu F, Liu H, et al. (2008) Two supporting factors greatly improve the efficiency of human iPSC generation. Cell Stem Cell 3: 475-479.

30. Mikkelsen TS, Hanna J, Zhang X, Ku M, Wernig M, et al. (2008) Dissecting direct reprogramming through integrative genomic analysis. Nature 454: 49-55.

31. Shi Y, Do JT, Desponts C, Hahm HS, Schöler HR, et al. (2008) A combined chemical and genetic approach for the generation of induced pluripotent stem cells. Cell Stem Cell 2: 525-528.

32. Huangfu D, Maehr R, Guo W, Eijkelenboom A, Snitow M, et al. (2008) Induction of pluripotent stem cells by defined factors is greatly improved by smallmolecule compounds. Nat Biotechnol 26: 795-797.

33. Shi Y, Desponts C, Do JT, Hahm HS, Schöler HR, et al. (2008) Induction of pluripotent stem cells from mouse embryonic fibroblasts by Oct4 and Klf4 with small-molecule compounds. Cell Stem Cell 3: 568-574

34. Li W, Wei W, Zhu S, Zhu J, Shi Y, et al. (2009) Generation of rat and human induced pluripotent stem cells by combining genetic reprogramming and chemical inhibitors. Cell Stem Cell 4: 16-19.

35. Maherali N, Hochedlinger K (2009) Tgfbeta signal inhibition cooperates in the induction of iPSCs and replaces Sox2 and cMyc. Curr Biol 19: 1718-1723.

36. Ichida JK, Blanchard J, Lam K, Son EY, Chung JE, et al. (2009) A smallmolecule inhibitor of tgf-Beta signaling replaces sox2 in reprogramming by inducing nanog. Cell Stem Cell 5: 491-503.

37. Li Y, Zhang Q, Yin X, Yang W, Du Y, et al. (2011) Generation of iPSCs from mouse fibroblasts with a single gene, Oct4, and small molecules. Cell Res 21 : 196-204.

38. Zhu S, Li W, Zhou H, Wei W, Ambasudhan R, et al. (2010) Reprogramming of human primary somatic cells by OCT4 and chemical compounds. Cell Stem Cell 7: 651-655.

39. Staerk J, Lyssiotis CA, Medeiro LA, Bollong M, Foreman RK, et al. (2011) PanSrc family kinase inhibitors replace Sox 2 during the direct reprogramming of somatic cells. Angew Chem Int Ed Engl 50: 5734-5736.

40. Lyssiotis CA, Foreman RK, Staerk J, Garcia M, Mathur D, et al. (2009) Reprogramming of murine fibroblasts to induced pluripotent stem cells with chemical complementation of Klf4. Proc Natl Acad Sci USA 106: 8912-8917.

41. Marson A, Foreman R, Chevalier B, Bilodeau S, Kahn M, et al. (2008) Wn signaling promotes reprogramming of somatic cells to pluripotency. Cell Stem Cell 3: $132-135$

42. Brambrink T, Foreman R, Welstead GG, Lengner CJ, Wernig M, et al. (2008) Sequential expression of pluripotency markers during direct reprogramming of mouse somatic cells. Cell Stem Cell 2: 151-159.

43. Stadtfeld M, Maherali N, Breault DT, Hochedlinger K (2008) Defining molecular cornerstones during fibroblast to iPS cell reprogramming in mouse. Cell Stem Cell 2: $230-240$.

44. Hanna J, Saha K, Pando B, van Zon J, Lengner CJ, et al. (2009) Direct cell reprogramming is a stochastic process amenable to acceleration. Nature 462 $595-601$.

45. Li R, Liang J, Ni S, Zhou T, Qing X, Li H, et al. (2010) A mesenchymal-to- 
Citation: Young W, D’Souza SL, Lemischka IR, Schaniel C (2012) Patient-specific Induced Pluripotent Stem Cells as a Platform for Disease Modeling Drug Discovery and Precision Personalized Medicine. J Stem Cell Res Ther S10:010. doi:10.4172/2157-7633.S10-010

epithelial transition initiates and is required for the nuclear reprogramming of mouse fibroblasts. Cell Stem Cell 7: 51-63.

46. Samavarchi-Tehrani P, Golipour A, David L, Sung HK, Beyer TA, et al (2010) Functional genomics reveals a BMP-driven mesenchymal-to-epithelia transition in the initiation of somatic cell reprogramming. Cell Stem Cell 7: 6477.

47. Chin MH, Pellegrini M, Plath K, Lowry WE (2010) Molecular analyses of human induced pluripotent stem cells and embryonic stem cells. Cell Stem Cell 7: 263269.

48. Fussner E, Djuric U, Strauss M, Hotta A, Perez-Iratxeta C, et al. (2011) Constitutive heterochromatin reorganization during somatic cell reprogramming. EMBO J 30: 1778-1789.

49. Stadtfeld M, Nagaya M, Utikal J, Weir G, Hochedlinger K (2008) Induced pluripotent stem cells generated without viral integration. Science 322: 945949.

50. Okita K, Nakagawa M, Hyenjong H, Ichisaka T, Yamanaka S (2008) Generation of mouse induced pluripotent stem cells without viral vectors. Science 322 : 949-953.

51. Gonzalez F, Barragan Monasterio M, Tiscornia G, Montserrat Pulido N Vassena R, et al. (2009) Generation of mouse-induced pluripotent stem cells by transient expression of a single nonviral polycistronic vector. Proc Natl Acad Sci USA 106: 8918-8922.

52. Si-Tayeb K, Noto FK, Sepac A, Sedlic F, Bosnjak ZJ, et al. (2010) Generation of human induced pluripotent stem cells by simple transient transfection of plasmid DNA encoding reprogramming factors. BMC Dev Biol 10: 81.

53. Soldner F, Hockemeyer D, Beard C, Gao Q, Bell GW, et al. (2009) Parkinson's disease patient-derived induced pluripotent stem cells free of viral reprogramming factors. Cell 136: 964-977.

54. Chang CW, Lai YS, Pawlik KM, Liu K, Sun CW, et al. (2009) Polycistronic lentiviral vector for "hit and run" reprogramming of adult skin fibroblasts to induced pluripotent stem cells. Stem Cells 27: 1042-1049.

55. Somers A, Jean JC, Sommer CA, Omari A, Ford CC, et al. (2010) Generation of transgene-free lung disease-specific human induced pluripotent stem cells using a single excisable lentiviral stem cell cassette. Stem Cells 28: 1728-1740.

56. Yu J, Hu K, Smuga-Otto K, Tian S, Stewart R, et al. (2009) Human induced pluripotent stem cells free of vector and transgene sequences. Science 324 : 797-801

57. Jia F, Wilson KD, Sun N, Gupta DM, Huang M, Li Z, et al. (2010) A nonviral minicircle vector for deriving human iPS cells. Nat Methods 7: 197-199.

58. Kaji K, Norrby K, Paca A, Mileikovsky M, Mohseni P, et al. (2009) Virus-free induction of pluripotency and subsequent excision of reprogramming factors. Nature 458: 771-775

59. Woltjen K, Michael IP, Mohseni P, Desai R, Mileikovsky M, et al. (2009) piggyBac transposition reprograms fibroblasts to induced pluripotent stem cells. Nature 458: 766-770.

60. Yusa K, Rad R, Takeda J, Bradley A (2009) Generation of transgene-free induced pluripotent mouse stem cells by the piggyBac transposon. Nat Methods 6: 363-369.

61. Zhou H, Wu S, Joo JY, Zhu S, Han DW, et al. (2009) Generation of induced pluripotent stem cells using recombinant proteins. Cell Stem Cell 4: 381-384

62. Fusaki N, Ban H, Nishiyama A, Saeki K, Hasegawa M (2009) Efficient induction of transgene-free human pluripotent stem cells using a vector based on Sendai virus, an RNA virus that does not integrate into the host genome. Proc Jpn Acad Ser B Phys Biol Sci 85: 348-362.

63. Warren L, Manos PD, Ahfeldt T, Loh YH, Li H, et al. (2010) Highly efficien reprogramming to pluripotency and directed differentiation of human cells with synthetic modified mRNA. Cell Stem Cell 7: 618-630.

64. Miyoshi N, Ishii H, Nagano H, Haraguchi N, Dewi DL, et al. (2011) Reprogramming of mouse and human cells to pluripotency using mature microRNAs. Cell Stem Cell 8: 633-638.

65. Liu H, Zhu F, Yong J, Zhang P, Hou P, et al. (2008) Generation of induced pluripotent stem cells from adult rhesus monkey fibroblasts. Cell Stem Cell 3: 587-590.
66. Tomioka I, Maeda T, Shimada H, Kawai K, Okada Y, et al. (2010) Generating induced pluripotent stem cells from common marmoset (Callithrix jacchus) fetal liver cells using defined factors, including Lin28. Genes Cells 15: 959-969.

67. Liao J, Cui C, Chen S, Ren J, Chen J, et al. (2009) Generation of induced pluripotent stem cell lines from adult rat cells. Cell Stem Cell 4: 11-15.

68. Esteban MA, Xu J, Yang J, Peng M, Qin D, et al. (2009) Generation of induced pluripotent stem cell lines from Tibetan miniature pig. J Biol Chem 284: 17634 17640.

69. Wu Z, Chen J, Ren J, Bao L, Liao J, et al. (2009) Generation of pig induced pluripotent stem cells with a drug-inducible system. J Mol Cell Biol 1: 46-54.

70. Ezashi T, Telugu BP, Alexenko AP, Sachdev S, Sinha S, et al. (2009) Derivation of induced pluripotent stem cells from pig somatic cells. Proc Natl Acad Sci USA 106: 10993-10998.

71. Shimada H, Nakada A, Hashimoto Y, Shigeno K, Shionoya Y, et al. (2010) Generation of canine induced pluripotent stem cells by retroviral transduction and chemical inhibitors. Mol Reprod Dev 77: 2.

72. Luo J, Suhr ST, Chang EA, Wang K, Ross PJ, et al. (2011) Generation of leukemia inhibitory factor and basic fibroblast growth factor-dependent induced pluripotent stem cells from canine adult somatic cells. Stem Cells Dev 20 1669-1678.

73. Bao L, He L, Chen J, Wu Z, Liao J, et al. (2011) Reprogramming of ovine adult fibroblasts to pluripotency via drug-inducible expression of defined factors. Cell Res 21: 600-608.

74. Nagy K, Sung HK, Zhang P, Laflamme S, Vincent $P$, et al. (2011) Induced pluripotent stem cell lines derived from equine fibroblasts. Stem Cell Rev $7:$ 693-702.

75. Han X, Han J, Ding F, Cao S, Lim SS, et al. (2011) Generation of induced pluripotent stem cells from bovine embryonic fibroblast cells. Cell Res 21 1509-1512.

76. Selvaraj V, Wildt DE, Pukazhenthi BS (2011) Induced pluripotent stem cells for conserving endangered species? Nat Methods 8: 805-807.

77. Kulessa H, Frampton J, Graf T (1995) GATA-1 reprograms avian myelomonocytic cell lines into eosinophils, thromboblasts, and erythroblasts. Genes Dev 9: 1250-1262.

78. Xie H, Ye M, Feng R, Graf T (2004) Stepwise reprogramming of B cells into macrophages. Cell 117: 663-676.

79. Laiosa CV, Stadtfeld M, Xie H, de Andres-Aguayo L, Graf T (2006) Reprogramming of committed $T$ cell progenitors to macrophages and dendritic cells by C/EBP alpha and PU.1 transcription factors. Immunity 25: 731-744.

80. Zhou Q, Brown J, Kanarek A, Rajagopal J, Melton DA (2008) In vivo reprogramming of adult pancreatic exocrine cells to beta-cells. Nature 455 627-632.

81. Vierbuchen T, Ostermeier A, Pang ZP, Kokubu Y, Südhof TC, et al. (2010) Direct conversion of fibroblasts to functional neurons by defined factors. Nature 463: $1035-1041$

82. Pang ZP, Yang N, Vierbuchen T, Ostermeier A, Fuentes DR, et al. (2011) Induction of human neuronal cells by defined transcription factors. Nature 476 220-223.

83. Pfisterer U, Kirkeby A, Torper O, Wood J, Nelander J, et al. (2011) Direct conversion of human fibroblasts to dopaminergic neurons. Proc Natl Acad Sci USA 108: 10343-10348.

84. Caiazzo M, Dell'Anno MT, Dvoretskova E, Lazarevic D, Taverna S, et al. (2011) Direct generation of functional dopaminergic neurons from mouse and human fibroblasts. Nature 476: 224-227.

85. Ambasudhan R, Talantova M, Coleman R, Yuan X, Zhu S, et al. (2011) Direct reprogramming of adult human fibroblasts to functional neurons under defined conditions. Cell Stem Cell 9: 113-118.

86. Lujan E, Chanda S, Ahlenius H, Südhof TC, Wernig M (2012) Direct conversion of mouse fibroblasts to self-renewing, tripotent neural precursor cells. Proc Nat Acad Sci USA 109: 2527-2532.

87. Lee ST, Chu K, Jung KH, Song YM, Jeon D, et al. (2011) Direct generation of neurosphere-like cells from human dermal fibroblasts. PLoS One 6: e21801.

88. Han DW, Tapia N, Hermann A, Hemmer K, Höing S, et al. (2012) Direct 
Citation: Young W, D'Souza SL, Lemischka IR, Schaniel C (2012) Patient-specific Induced Pluripotent Stem Cells as a Platform for Disease Modeling, Drug Discovery and Precision Personalized Medicine. J Stem Cell Res Ther S10:010. doi:10.4172/2157-7633.S10-010

reprogramming of fibroblasts into neural stem cells by defined factors. Cell Stem Cell 10: 465-472.

89. Thier M, Wörsdörfer P, Lakes YB, Gorris R, Herms S, et al. (2012) Direct conversion of fibroblasts into stably expandable neural stem cells. Cell Stem Cell 10: 473-479.

90. Ring KL, Tong LM, Balestra ME, Javier R, Andrews-Zwilling Y, et al. (2012) Direct Reprogramming of Mouse and Human Fibroblasts into Multipotent Neural Stem Cells with a Single Factor. Cell Stem Cell 11: 100-109.

91. Huang $P$, He Z, Ji S, Sun $H$, Xiang $D$, et al. (2011) Induction of functional hepatocyte-like cells from mouse fibroblasts by defined factors. Nature 475 : 386-389

92. Sekiya S, Suzuki A (2011) Direct conversion of mouse fibroblasts to hepatocytelike cells by defined factors. Nature 475: 390-393.

93. leda M, Fu JD, Delgado-Olguin P, Vedantham V, Hayashi Y, et al. (2010) Direct reprogramming of fibroblasts into functional cardiomyocytes by defined factors. Cell 142: 375-386.

94. Jayawardena TM, Egemnazarov B, Finch EA, Zhang L, Payne JA, et al. (2012) MicroRNA-Mediated In Vitro and In Vivo Direct Reprogramming of Cardiac Fibroblasts to Cardiomyocytes. Circ Res 110: 1465-1473.

95. Protze S, Khattak S, Poulet C, Lindemann D, Tanaka EM, et al. (2012) A new approach to transcription factor screening for reprogramming of fibroblasts to cardiomyocyte-like cells. J Mol Cell Cardiol 53: 323-332.

96. Chen JX, Krane M, Deutsch MA, Wang L, Rav-Acha M, et al. (2012) Inefficient reprogramming of fibroblasts into cardiomyocytes using gata4, mef2c, and tbx5. Circ Res 111: 50-55.

97. Song K, Nam YJ, Luo X, Qi X, Tan W, et al. (2012) Heart repair by reprogramming non-myocytes with cardiac transcription factors. Nature 485: 599-604.

98. Qian L, Huang Y, Spencer Cl, Foley A, Vedantham V, et al. (2012) In vivo reprogramming of murine cardiac fibroblasts into induced cardiomyocytes. Nature 485: 593-598.

99. Efe JA, Hilcove S, Kim J, Zhou H, Ouyang K, et al. (2011) Conversion of mouse fibroblasts into cardiomyocytes using a direct reprogramming strategy. Nat Cell Biol 13: 215-222

100. Kim J, Efe JA, Zhu S, Talantova M, Yuan X, et al. (2011) Direct reprogramming of mouse fibroblasts to neural progenitors. Proc Natl Acad Sci USA 108: 78387843

101.Szabo E, Rampalli S, Risueño RM, Schnerch A, Mitchell R, et al. (2010) Direct conversion of human fibroblasts to multilineage blood progenitors. Nature 468 521-526.

102. Hanna J, Wernig M, Markoulaki S, Sun CW, Meissner A, et al. (2007) Treatment of sickle cell anemia mouse model with iPS cells generated from autologous skin. Science 318: 1920-1923.

103. Israel MA, Yuan SH, Bardy C, Reyna SM, Mu Y, et al. (2012) Probing sporadic and familial Alzheimer's disease using induced pluripotent stem cells. Nature 482: $216-220$

104. Brennand KJ, Simone A, Jou J, Gelboin-Burkhart C, Tran N, et al. (2011) Modelling schizophrenia using human induced pluripotent stem cells. Nature 473: $221-225$

105. Paulsen BD, Maciel RD, Galina A, da Silveira MS, Souza CD, et al. (2011) Altered oxygen metabolism associated to neurogenesis of induced pluripotent stem cells derived from a schizophrenic patient. Cell Transplant [Epub ahead of print]

106. Lowry WE, Richter L, Yachechko R, Pyle AD, Tchieu, et al. (2008) Generation of human induced pluripotent stem cells from dermal fibroblasts. Proc Natl Acad Sci USA 105: 2883-2888.

107. Ellis J, Bruneau BG, Keller G, Lemischka IR, Nagy A, et al. (2009) Alternative induced pluripotent stem cell characterization criteria for in vitro applications. Cell Stem Cell 4: 198-199.

108. Daley GQ, Lensch MW, Jaenisch R, Meissner A, Plath K, et al. (2009) Broader implications of defining standards for the pluripotency of iPSCs. Cell Stem Cell 4: 200-201.

109. Maherali N, Hochedlinger K (2008) Guidelines and techniques for the generation of induced pluripotent stem cells. Cell Stem Cell 3: 595-605.
110. Sullivan GJ, Bai Y, Fletcher J, Wilmut I (2010) Induced pluripotent stem cells: epigenetic memories and practical implications. Mol Hum Reprod 16: 880-885

111. Nishino K, Toyoda M, Yamazaki-Inoue M, Fukawatase $Y$, Chikazawa E, et al (2011) DNA methylation dynamics in human induced pluripotent stem cells over time. PLoS Genet 7: e1002085.

112. Leavitt AD, Hamlett I (2011) Homologous recombination in human embryonic stem cells: a tool for advancing cell therapy and understanding and treating human disease. Clin TransI Sci 4: 298-305.

113. Howden SE, Gore A, Li Z, Fung HL, Nisler BS, et al. (2011) Genetic correction and analysis of induced pluripotent stem cells from a patient with gyrate atrophy. Proc Natl Acad Sci USA 108: 6537-6542.

114. Wang Y, Zheng CG, Jiang Y, Zhang J, Chen J, et al. (2012) Genetic correction of beta-thalassemia patient-specific iPS cells and its use in improving hemoglobin production in irradiated SCID mice. Cell Res 22: 637-648.

115. An MC, Zhang N, Scott G, Montoro D, Wittkop T, et al. (2012) Genetic Correction of Huntington's Disease Phenotypes in Induced Pluripotent Stem Cells. Cell Stem Cell 11: 253-263.

116. Liu GH, Suzuki K, Qu J, Sancho-Martinez I, Yi F, et al. (2011) Targeted gene correction of laminopathy-associated LMNA mutations in patient-specific iPSCs. Cell Stem Cell 8: 688-694.

117.Zou J, Mali P, Huang X, Dowey SN, Cheng L (2011) Site-specific gene correction of a point mutation in human iPS cells derived from an adult patien with sickle cell disease. Blood 118: 4599-4608.

118. Sebastiano V, Maeder ML, Angstman JF, Haddad B, Khayter C, et al. (2011) In situ genetic correction of the sickle cell anemia mutation in human induced pluripotent stem cells using engineered zinc finger nucleases. Stem Cells 29 : 1717-1726.

119. Soldner F, Laganière J, Cheng AW, Hockemeyer D, Gao Q, et al. (2011) Generation of isogenic pluripotent stem cells differing exclusively at two early onset Parkinson point mutations. Cell 146: 318-331.

120.Boch J, Bonas U (2010) Xanthomonas AvrBs3 family-type III effectors: discovery and function. Annu Rev Phytopathol 48: 419-436.

121. Hockemeyer D, Wang H, Kiani S, Lai CS, Gao Q, et al. (2011) Genetic engineering of human pluripotent cells using TALE nucleases. Nat Biotechnol 29: 731-734.

122. Seyhan AA (2011) RNAi: a potential new class of therapeutic for human genetic disease. Hum Genet 130: 583-605.

123. Ku S, Soragni E, Campau E, Thomas EA, Altun G, et al. (2010) Friedreich's ataxia induced pluripotent stem cells model intergenerational GAA.TTC triple repeat instability. Cell Stem Cell 7: 631-637.

124. Kehat I, Kenyagin-Karsenti D, Snir M, Segev H, Amit M, et al. (2001) Human embryonic stem cells can differentiate into myocytes with structural and functional properties of cardiomyocytes. J Clin Invest 108: 407-414.

125. Xu XQ, Soo SY, Sun W, Zweigerdt R (2009) Global expression profile of highly enriched cardiomyocytes derived from human embryonic stem cells. Stem Cells 27: 2163-2174.

126. Slukvin II, Vodyanik MA, Thomson JA, Gumenyuk ME, Choi KD (2006) Directed differentiation of human embryonic stem cells into functional dendritic cells through the myeloid pathway. J Immunol 176: 2924-2932.

127. Erceg S, Laínez S, Ronaghi M, Stojkovic P, Pérez-Aragó MA, et al. (2008) Differentiation of human embryonic stem cells to regional specific neural precursors in chemically defined medium conditions. PLoS One 3: e2122.

128. D'Amour KA, Bang AG, Eliazer S, Kelly OG, Agulnick AD, et al. (2006) Production of pancreatic hormone-expressing endocrine cells from human embryonic stem cells. Nat Biotechnol 24: 1392-1401.

129. Chambers SM, Fasano CA, Papapetrou EP, Tomishima M, Sadelain M, et al. (2009) Highly efficient neural conversion of human ES and iPS cells by dual inhibition of SMAD signaling. Nat Biotechnol 27: 275-280.

130. Chen S, Borowiak M, Fox JL, Maehr R, Osafune K, et al. (2009) A smal molecule that directs differentiation of human ESCs into the pancreatic lineage. Nat Chem Biol 5: 258-265.

131. Borowiak M, Maehr R, Chen S, Chen AE, Tang W, et al. (2009) Small molecules efficiently direct endodermal differentiation of mouse and human embryonic stem cells. Cell Stem Cell 4: 348-358.

132. Kriks S, Shim JW, Piao J, Ganat YM, Wakeman DR, et al. (2011) Dopamine 
Citation: Young W, D'Souza SL, Lemischka IR, Schaniel C (2012) Patient-specific Induced Pluripotent Stem Cells as a Platform for Disease Modeling, Drug Discovery and Precision Personalized Medicine. J Stem Cell Res Ther S10:010. doi:10.4172/2157-7633.S10-010

neurons derived from human ES cells efficiently engraft in animal models of Parkinson's disease. Nature 480: 547-551.

133. Menendez L, Yatskievych TA, Antin PB, Dalton S (2011) Wnt signaling and a Smad pathway blockade direct the differentiation of human pluripotent stem cells to multipotent neural crest cells. Proc Natl Acad Sci USA 108: 1924019245.

134.Lock LT, Tzanakakis ES (2009) Expansion and differentiation of human embryonic stem cells to endoderm progeny in a microcarrier stirred-suspension culture. Tissue Eng Part A 15: 2051-2063.

135. Krawetz R, Taiani JT, Liu S, Meng G, Li X, et al. (2010) Large-scale expansion of pluripotent human embryonic stem cells in stirred-suspension bioreactors. Tissue Eng Part C Methods 16: 573-582.

136. Shafa M, Sjonnesen K, Yamashita A, Liu S, Michalak M, et al. (2012) Expansion and long-term maintenance of induced pluripotent stem cells in stirred suspension bioreactors. J Tissue Eng Regen Med 6: 462-472.

137. Abbasalizadeh S, Larijani MR, Samadian A, Baharvand H (2012) Bioprocess Development for Mass Production of Size-Controlled Human Pluripotent Stem Cell Aggregates in Stirred Suspension Bioreactor. Tissue Eng Part C Methods [Epub ahead of print]

138. Niebruegge S, Bauwens CL, Peerani R, Thavandiran N, Masse S, et al. (2009) Generation of human embryonic stem cell-derived mesoderm and cardiac cells using size-specified aggregates in an oxygen-controlled bioreactor. Biotechnol Bioeng 102: 493-507.

139. Schulz TC, Young HY, Agulnick AD, Babin MJ, Baetge EE, et al. (2012) A scalable system for production of functional pancreatic progenitors from human embryonic stem cells. PLoS One 7: e37004.

140. Carvajal-Vergara X, Sevilla A, D'Souza SL, Ang YS, Schaniel C, et al. (2010) Patient-specific induced pluripotent stem-cell-derived models of LEOPARD syndrome. Nature 465: 808-812.

141.Schadt EE (2009) Molecular networks as sensors and drivers of common human diseases. Nature 461: 218-223.

142. Hankowski KE, Hamazaki T, Umezawa A, Terada N (2011) Induced pluripotent stem cells as a next-generation biomedical interface. Lab Invest 91: 972-977.

143. Kasarskis A, Yang X, Schadt E (2011) Integrative genomics strategies to elucidate the complexity of drug response. Pharmacogenomics 12: 16951715 .

144. Fleiss JL (1993) The statistical basis of meta-analysis. Stat Methods Med Res 2: $121-145$

145. Mantel N, Haenszel W (1959) Statistical aspects of the analysis of data from retrospective studies of disease. J Natl Cancer Inst 22: 719-748.

146. Guo L, Abrams RM, Babiarz JE, Cohen JD, Kameoka S, et al. (2011) Estimating the risk of drug-induced proarrhythmia using human induced pluripotent stem cell-derived cardiomyocytes. Toxicol Sci 123: 281-289.

147.Lian Q, Chow Y, Esteban MA, Pei D, Tse HF (2010) Future perspective of induced pluripotent stem cells for diagnosis, drug screening and treatment of human diseases. Thromb Haemost 104: 39-44.

148. Tanaka T, Tohyama S, Murata M, Nomura F, Kaneko T, et al. (2009) In vitro pharmacologic testing using human induced pluripotent stem cell-derived cardiomyocytes. Biochem Biophys Res Commun 385: 497-502.

149. Yokoo N, Baba S, Kaichi S, Niwa A, Mima T, et al. (2009) The effects of cardioactive drugs on cardiomyocytes derived from human induced pluripotent stem cells. Biochem Biophys Res Commun 387: 482-488.

150.Jung CB, Moretti A, Mederos y Schnitzler M, lop L, Storch U, et al. (2012) Dantrolene rescues arrhythmogenic RYR2 defect in a patient-specific stem cell model of catecholaminergic polymorphic ventricular tachycardia. EMBO Mol Med 4: 180-191.

151. Lee G, Papapetrou EP, Kim H, Chambers SM, Tomishima MJ, et al. (2009) Modelling pathogenesis and treatment of familial dysautonomia using patientspecific iPSCs. Nature 461: 402-406.

152. Ebert AD, Yu J, Rose FF Jr, Mattis VB, Lorson CL, et al. (2009) Induced pluripotent stem cells from a spinal muscular atrophy patient. Nature 457 : 277-280.

153. Marchetto MC, Carromeu C, Acab A, Yu D, Yeo GW, et al. (2010) A model for neural development and treatment of Rett syndrome using human induced pluripotent stem cells. Cell 143: 527-539.
154. Yagi T, Ito D, Okada Y, Akamatsu W, Nihei Y, et al. (2011) Modeling familial Alzheimer's disease with induced pluripotent stem cells. Hum Mol Genet 20: 4530-4539.

155. Yahata N, Asai M, Kitaoka S, Takahashi K, Asaka I, et al. (2011) Anti-Abeta drug screening platform using human iPS cell-derived neurons for the treatment of Alzheimer's disease. PLoS One 6: e25788.

156. Cooper O, Seo H, Andrabi S, Guardia-Laguarta C, Graziotto J, et al. (2012) Pharmacological Rescue of Mitochondrial Deficits in iPSC-Derived Neura Cells from Patients with Familial Parkinson's Disease. Sci Transl Med 4: 141 ra190.

157. Kim HJ, Jin CY (2012) Stem cells in drug screening for neurodegenerative disease. Korean J Physiol Pharmacol 16: 1-9.

158. Ooi L, Sidhu K, Poljak A, Sutherland G, O'Connor MD, et al. (2012) Induced pluripotent stem cells as tools for disease modelling and drug discovery in Alzheimer's disease. J Neural Transm [Epub ahead of print]

159. Green RM (2002) Benefiting from 'evil': an incipient moral problem in human stem cell research. Bioethics 16: 544-556.

160. George RP, Gomez-Lobo A (2005) The moral status of the human embryo. Perspect Biol Med 48: 201-210.

161. Charron D, Suberbielle-Boissel C, Al-Daccak R (2009) Immunogenicity and allogenicity: a challenge of stem cell therapy. J Cardiovasc Transl Res 2: 130 138.

162. Kim K, Doi A, Wen B, Ng K, Zhao R, et al. (2010) Epigenetic memory in induced pluripotent stem cells. Nature 467: 285-290.

163. Hu Q, Friedrich AM, Johnson LV, Clegg DO (2010) Memory in induced pluripotent stem cells: reprogrammed human retinal-pigmented epithelial cells show tendency for spontaneous redifferentiation. Stem Cells 28: 1981-1991.

164. Lister R, Pelizzola M, Kida YS, Hawkins RD, Nery JR, et al. (2011) Hotspots of aberrant epigenomic reprogramming in human induced pluripotent stem cells. Nature 471: 68-73.

165. Ohi Y, Qin H, Hong C, Blouin L, Polo JM, et al. (2011) Incomplete DNA methylation underlies a transcriptional memory of somatic cells in human iPS cells. Nat Cell Biol 13: 541-549.

166. Bar-Nur O, Russ HA, Efrat S, Benvenisty N (2011) Epigenetic memory and preferential lineage-specific differentiation in induced pluripotent stem cells derived from human pancreatic islet beta cells. Cell Stem Cell 9: 17-23.

167. Gore A, Li Z, Fung HL, Young JE, Agarwal S, et al. (2011) Somatic coding mutations in human induced pluripotent stem cells. Nature 471: 63-67.

168. Taapken SM, Nisler BS, Newton MA, Sampsell-Barron TL, Leonhard KA, et al. (2011) Karotypic abnormalities in human induced pluripotent stem cells and embryonic stem cells. Nat Biotechnol 29: 313-314.

169. Martins-Taylor K, Nisler BS, Taapken SM, Compton T, Crandall, et al. (2011) Recurrent copy number variations in human induced pluripotent stem cells. Nat Biotechnol 29: 488-491.

170. Quinlan AR, Boland MJ, Leibowitz ML, Shumilina S, Pehrson SM, et al (2011) Genome sequencing of mouse induced pluripotent stem cells reveals retroelement stability and infrequent DNA rearrangement during reprogramming. Cell Stem Cell 9: 366-373.

171. Ji J, Ng SH, Sharma V, Neculai D, Hussein S, et al. (2012) Elevated coding mutation rate during the reprogramming of human somatic cells into induced pluripotent stem cells. Stem Cells 30: 435-440.

172. Cheng L, Hansen NF, Zhao L, Du Y, Zou C, et al. (2012) Low incidence of DNA sequence variation in human induced pluripotent stem cells generated by nonintegrating plasmid expression. Cell Stem Cell 10: 337-344.

173. Young MA, Larson DE, Sun CW, George DR, Ding L, et al. (2012) Background mutations in parental cells account for most of the genetic heterogeneity of induced pluripotent stem cells. Cell Stem Cell 10: 570-582.

174.Zhao T, Zhang ZN, Rong Z, Xu Y (2011) Immunogenicity of induced pluripotent stem cells. Nature 474: 212-215.

175. Wernig M, Zhao JP, Pruszak J, Hedlund E, Fu D, et al. (2008) Neurons derived from reprogrammed fibroblasts functionally integrate into the fetal brain and improve symptoms of rats with Parkinson's disease. Proc Natl Acad Sci USA 105: $5856-5861$.

176.Xu D, Alipio Z, Fink LM, Adcock DM, Yang J, et al. (2009) Phenotypic 
Citation: Young W, D'Souza SL, Lemischka IR, Schaniel C (2012) Patient-specific Induced Pluripotent Stem Cells as a Platform for Disease Modeling, Drug Discovery and Precision Personalized Medicine. J Stem Cell Res Ther S10:010. doi:10.4172/2157-7633.S10-010

Page 13 of 14

correction of murine hemophilia A using an iPS cell-based therapy. Proc Natl Acad Sci USA 106: 808-813

177. Tsuji O, Miura K, Okada Y, Fujiyoshi K, Mukaino M, et al. (2010) Therapeutic potential of appropriately evaluated safe-induced pluripotent stem cells for spinal cord injury. Proc Natl Acad Sci USA 107: 12704-12709.

178. Goldring CE, Duffy PA, Benvenisty N, Andrews PW, Ben-David U, et al. (2011) Assessing the safety of stem cell therapeutics. Cell Stem Cell 8: 618-628.

179. Issa AM (2007) Personalized medicine and the practice of medicine in the $21 \mathrm{st}$ century. Mcgill J Med 10: 53-57.

180. Gardiner SJ, Begg EJ (2006) Pharmacogenetics, drug-metabolizing enzymes, and clinical practice. Pharmacol Rev 58: 521-590.

181.Wang L (2010) Pharmacogenomics: a systems approach. Wiley Interdiscip Rev Syst Biol Med 2: 3-22.

182. Rashid ST, Corbineau S, Hannan N, Marciniak SJ, Miranda E, et al. (2010) Modeling inherited metabolic disorders of the liver using human induced pluripotent stem cells. J Clin Invest 120: 3127-3136.

183. Jang J, Kang HC, Kim HS, Kim JY, Huh YJ, et al. (2011) Induced pluripotent stem cell models from X-linked adrenoleukodystrophy patients. Ann Neurol 70: 402-409.

184. Mitne-Neto M, Machado-Costa M, Marchetto MC, Bengtson MH, Joazeiro CA et al. (2011) Downregulation of VAPB expression in motor neurons derived from induced pluripotent stem cells of ALS8 patients. Hum Mol Genet 20: 3642-3652.

185. Bilican B, Serio A, Barmada SJ, Nishimura AL, Sullivan GJ, et al. (2012) Mutant induced pluripotent stem cell lines recapitulate aspects of TDP-43 proteinopathies and reveal cell-specific vulnerability. Proc Natl Acad Sci USA 109: 5803-5808.

186. Novak A, Barad L, Zeevi-Levin N, Shick R, Shtrichman R, et al. (2012) Cardiomyocytes generated from CPVTD307H patients are arrhythmogenic in response to beta-adrenergic stimulation. J Cell Mol Med 16: 468-482.

187. Fatima A, Xu G, Shao K, Papadopoulos S, Lehmann M, et al. (2011) In vitro modeling of ryanodine receptor 2 dysfunction using human induced pluripotent stem cells. Cell Physiol Biochem 28: 579-592.

188. Itzhaki I, Maizels L, Huber I, Gepstein A, Arbel G, et al. (2012) Modeling of Catecholaminergic Polymorphic Ventricular Tachycardia With Patient-Specific Human-Induced Pluripotent Stem Cells. J Am Coll Cardiol 60: 990-1000.

189.Zou J, Sweeney CL, Chou BK, Choi U, Pan J, et al. (2011) Oxidase-deficient neutrophils from $X$-linked chronic granulomatous disease iPS cells: functional correction by zinc finger nuclease-mediated safe harbor targeting. Blood 117: 5561-5572.

190. Jiang Y, Cowley SA, Siler U, Melguizo D, Tilgner K, et al. (2012) Derivation and functional analysis of patient-specific induced pluripotent stem cells as an in vitro model of chronic granulomatous disease. Stem Cells 30: 599-611.

191. Tanaka T, Takahashi K, Yamane M, Tomida S, Nakamura S, et al. (2012) Induced pluripotent stem cells from CINCA syndrome patients as a model for dissecting somatic mosaicism and drug discovery. Blood 120: 1299-1308.

192. Kumano K, Arai S, Hosoi M, Taoka K, Takayama N, et al. (2012) Generation of induced pluripotent stem cells from primary chronic myelogenous leukemia patient samples. Blood 119: 6234-6242.

193. Ho JC, Zhou T, Lai WH, Huang Y, Chan YC, et al. (2011) Generation of induced pluripotent stem cell lines from 3 distinct laminopathies bearing heterogeneous mutations in lamin A/C. Aging (Albany NY) 3: 380-390.

194. Sun N, Yazawa M, Liu J, Han L, Sanchez-Freire V, et al. (2012) Patient-specific induced pluripotent stem cells as a model for familial dilated cardiomyopathy. Sci Transl Med 4: 130ra47.

195. Baek KH, Zaslavsky A, Lynch RC, Britt C, Okada Y, et al. (2009) Down's syndrome suppression of tumour growth and the role of the calcineurin inhibitor DSCR1. Nature 459: 1126-1130.

196. Shi Y, Kirwan P, Smith J, MacLean G, Orkin SH, et al. (2012) A human stem cell model of early Alzheimer's disease pathology in Down syndrome. Sci Transl Med 4: $124 \mathrm{ra29.}$

197. Agarwal S, Loh YH, McLoughlin EM, Huang J, Park IH, et al. (2010) Telomere elongation in induced pluripotent stem cells from dyskeratosis congenita patients. Nature 464: 292-296.

198. Batista LF, Pech MF, Zhong FL, Nguyen HN, Xie KT, et al. (2011) Telomere shortening and loss of self-renewal in dyskeratosis congenita induced pluripotent stem cells. Nature 474: 399-402

199. Cayo MA, Cai J, Delaforest A, Noto FK, Nagaoka M, et al. (2012) JD induced pluripotent stem cell-derived hepatocytes faithfully recapitulate the pathophysiology of familial hypercholesterolemia. Hepatology [Epub ahead of print]

200. Sheridan SD, Theriault KM, Reis SA, Zhou F, Madison JM, et al. (2011) Epigenetic characterization of the FMR1 gene and aberrant neurodevelopment in human induced pluripotent stem cell models of fragile $X$ syndrome. PLoS One 6: e26203.

201. Mazzulli JR, Xu YH, Sun Y, Knight AL, McLean PJ, et al. (2011) Gaucher disease glucocerebrosidase and alpha-synuclein form a bidirectional pathogenic loop in synucleinopathies. Cell 146: 37-52.

202.Zhang N, An MC, Montoro D, Ellerby LM (2010) Characterization of Human Huntington's Disease Cell Model from Induced Pluripotent Stem Cells. PLoS Curr 2: RRN1193.

203. Camnasio S, Carri AD, Lombardo A, Grad I, Mariotti C, et al. (2012) The first reported generation of several induced pluripotent stem cell lines from homozygous and heterozygous Huntington's disease patients demonstrates mutation related enhanced lysosomal activity. Neurobiol Dis 46: 41-51.

204. Juopperi TA, Kim WR, Chiang CH, Yu H, Margolis RL, et al. (2012) Astrocytes generated from patient induced pluripotent stem cells recapitulate features of Huntington's disease patient cells. Mol Brain 5: 17.

205. The Hd Ipsc Consortium (2012) Induced Pluripotent Stem Cells from Patients with Huntington's Disease Show CAG-Repeat-Expansion-Associated Phenotypes. Cell Stem Cell 11: 264-278.

206. Tolar J, Park IH, Xia L, Lees CJ, Peacock B, et al. (2011) Hematopoietic differentiation of induced pluripotent stem cells from patients with mucopolysaccharidosis type I (Hurler syndrome). Blood 117: 839-847.

207.Zhang J, Lian Q, Zhu G, Zhou F, Sui L, et al. (2011) A human iPSC mode of Hutchinson Gilford Progeria reveals vascular smooth muscle and mesenchymal stem cell defects. Cell Stem Cell 8: 31-45.

208. Liu GH, Barkho BZ, Ruiz S, Diep D, Qu J, et al. (2011) Recapitulation of premature ageing with iPSCs from Hutchinson-Gilford progeria syndrome. Nature 472: 221-225.

209.Davis RP, Casini S, van den Berg CW, Hoekstra M, Remme CA, et al (2012) Cardiomyocytes derived from pluripotent stem cells recapitulate electrophysiological characteristics of an overlap syndrome of cardiac sodium channel disease. Circulation 125: 3079-3091.

210. Moretti A, Bellin M, Welling A, Jung CB, Lam JT, et al. (2010) Patient-specific induced pluripotent stem-cell models for long-QT syndrome. N Engl J Med 363: 1397-1409.

211. Itzhaki I, Maizels L, Huber I, Zwi-Dantsis L, Caspi O, et al. (2011) Modelling the long QT syndrome with induced pluripotent stem cells. Nature 471: 225-229.

212. Yazawa M, Hsueh B, Jia X, Pasca AM, Bernstein JA, et al. (2011) Using induced pluripotent stem cells to investigate cardiac phenotypes in Timothy syndrome. Nature 471: 230-234.

213. Malan D, Friedrichs S, Fleischmann BK, Sasse P (2011) Cardiomyocytes obtained from induced pluripotent stem cells with long-QT syndrome 3 recapitulate typical disease-specific features in vitro. Circ Res 109: 841-847.

214. Lahti AL, Kujala VJ, Chapman H, Koivisto AP, Pekkanen-Mattila M, et al. (2012) Model for long QT syndrome type 2 using human iPS cells demonstrates arrhythmogenic characteristics in cell culture. Dis Model Mech 5: 220-230.

215. Egashira T, Yuasa S, Suzuki T, Aizawa Y, Yamakawa H, et al. (2012) Disease characterization using LQTS-specific induced pluripotent stem cells. Cardiovasc Res 95: 419-429.

216. Koch P, Breuer P, Peitz M, Jungverdorben J, Kesavan J, et al. (2011) Excitation-induced ataxin-3 aggregation in neurons from patients with Machado-Joseph disease. Nature 480: 543-546.

217. Quarto N, Leonard B, Li S, Marchand M, Anderson E, et al. (2012) Skeletogenic phenotype of human Marfan embryonic stem cells faithfully phenocopied by patient-specific induced-pluripotent stem cells. Proc Natl Acad Sci USA 109 $215-220$

218. Lemonnier T, Blanchard S, Toli D, Roy E, Bigou S, et al. (2011) Modeling 
Citation: Young W, D'Souza SL, Lemischka IR, Schaniel C (2012) Patient-specific Induced Pluripotent Stem Cells as a Platform for Disease Modeling Drug Discovery and Precision Personalized Medicine. J Stem Cell Res Ther S10:010. doi:10.4172/2157-7633.S10-010

Page 14 of 14

neuronal defects associated with a lysosomal disorder using patient-derived induced pluripotent stem cells. Hum Mol Genet 20: 3653-3666.

219. Nguyen HN, Byers B, Cord B, Shcheglovitov A, Byrne J, et al. (2011) LRRK2 mutant iPSC-derived DA neurons demonstrate increased susceptibility to oxidative stress. Cell Stem Cell 8: 267-280.

220.Seibler P, Graziotto J, Jeong H, Simunovic F, Klein C, et al. (2011) Mitochondrial Parkin recruitment is impaired in neurons derived from mutant PINK1 induced pluripotent stem cells. J Neurosci 31: 5970-5976.

221. Devine MJ, Ryten M, Vodicka P, Thomson AJ, Burdon T, et al. (2011) Parkinson's disease induced pluripotent stem cells with triplication of the alpha-synuclein locus. Nat Commun 2: 440.

222. Byers B, Cord B, Nguyen HN, Schüle B, Fenno L, et al. (2011) SNCA triplication Parkinson's patient's iPSC-derived DA neurons accumulate alphasynuclein and are susceptible to oxidative stress. PLoS One 6: e26159.

223. Sánchez-Danés A, Richaud-Patin Y, Carballo-Carbajal I, Jiménez-Delgado S, Caig C, et al. (2012) Disease-specific phenotypes in dopamine neurons from human iPS-based models of genetic and sporadic Parkinson's disease. EMBO Mol Med 4: 380-395.

224. Ye Z, Zhan H, Mali P, Dowey S, Williams DM, et al. (2009) Human-induced pluripotent stem cells from blood cells of healthy donors and patients with acquired blood disorders. Blood 114: 5473-5480.

225. Huang HP, Chen PH, Hwu WL, Chuang CY, Chien YH, et al. (2011) Human Pompe disease-induced pluripotent stem cells for pathogenesis modeling, drug testing and disease marker identification. Hum Mol Genet 20: 4851-4864.

226. Yang J, Cai J, Zhang Y, Wang X, Li W, et al. (2010) Induced pluripotent stem cells can be used to model the genomic imprinting disorder Prader-Willi syndrome. J Biol Chem 285: 40303-40311.

227. Jin ZB, Okamoto S, Osakada F, Homma K, Assawachananont J, et al. (2011) Modeling retinal degeneration using patient-specific induced pluripotent stem cells. PLoS One 6: e17084.

228. Muotri AR, Marchetto MC, Coufal NG, Oefner R, Yeo G, et al. (2010) L1 retrotransposition in neurons is modulated by MeCP2. Nature 468: 443-446.

229. Cheung AY, Horvath LM, Grafodatskaya D, Pasceri $P$, Weksberg $R$, et al. (2011) Isolation of MECP2-null Rett Syndrome patient hiPS cells and isogenic controls through X-chromosome inactivation. Hum Mol Genet 20: 2103-2115.

230. Kim KY, Hysolli E, Park IH (2011) Neuronal maturation defect in induced pluripotent stem cells from patients with Rett syndrome. Proc Natl Acad Sci USA 108: 14169-14174.

231. Ananiev G, Williams EC, Li H, Chang Q (2011) Isogenic pairs of wild type and mutant induced pluripotent stem cell (iPSC) lines from Rett syndrome patients as in vitro disease model. PLoS One 6: e25255.

232. Chang T, Zheng W, Tsark W, Bates S, Huang H, et al. (2011) Brief report phenotypic rescue of induced pluripotent stem cell-derived motoneurons of a spinal muscular atrophy patient. Stem Cells 29: 2090-2093.

233. Paşca SP, Portmann T, Voineagu I, Yazawa M, Shcheglovitov A, et al. (2011) Using iPSC-derived neurons to uncover cellular phenotypes associated with Timothy syndrome. Nat Med 17: 1657-1662.

234.Zhang S, Chen S, Li W, Guo X, Zhao P, et al. (2011) Rescue of ATP7B function in hepatocyte-like cells from Wilson's disease induced pluripotent stem cells using gene therapy or the chaperone drug curcumin. Hum Mo Genet 20: 3176-3187

This article was originally published in a special issue, Embryonic and Induced Pluripotent Stem Cells handled by Editor(s). Dr. Jianlong Wang, Mount Sinai School of Medicine, United States 